2015 Annual Reuse Report for the Idaho National Laboratory Site's Advanced Test Reactor Complex Cold Waste Ponds

February 2016

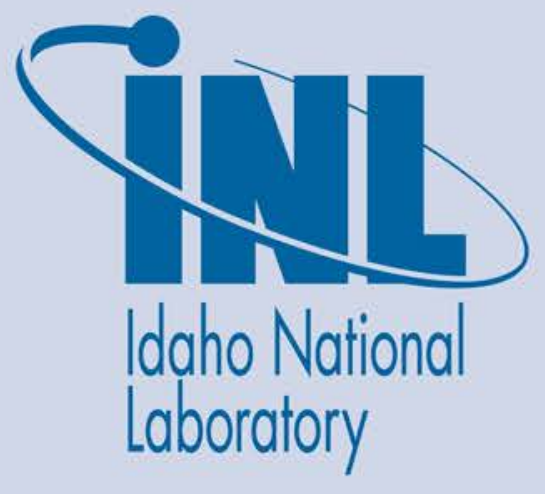

The INL is a U.S. Department of Energy National Laboratory operated by Battelle Energy Alliance 



\section{Annual Reuse Report for the Idaho National Laboratory Site's Advanced Test Reactor Complex Cold Waste Ponds}

February 2016

Idaho National Laboratory Idaho Falls, Idaho 83415

http://www.inl.gov

Prepared for the

U.S. Department of Energy

Office of Nuclear Energy, Science, and Technology

Under DOE Idaho Operations Office

Contract DE-AC07-05ID14517 



\begin{abstract}
This report describes conditions and information, as required by the state of Idaho, Department of Environmental Quality Reuse Permit I-161-02, for the Advanced Test Reactor Complex Cold Waste Ponds located at Idaho National Laboratory from November 1, 2014-October 31,2015. The effective date of Reuse Permit I-161-02 is November 20, 2014 with an expiration date of November 19, 2019. This report contains the following information:

- Facility and system description

- $\quad$ Permit required effluent monitoring data and loading rates

- $\quad$ Permit required groundwater monitoring data

- Status of compliance activities

- Noncompliance issues

- Discussion of the facility's environmental impacts.

During the 2015 permit year, approximately 228 million gallons of wastewater were discharged to the Cold Waste Ponds. This is well below the maximum annual permit limit of 375 million gallons.

As shown by the groundwater sampling data, sulfate and total dissolved solids concentrations are highest in well USGS-065, which is the closest downgradient well to the Cold Waste Ponds. Sulfate and total dissolved solids concentrations decrease rapidly as the distance downgradient from the Cold Waste Ponds increases. Although concentrations of sulfate and total dissolved solids are significantly higher in well USGS-065 than in the other monitoring wells, both parameters were below the Ground Water Quality Rule Secondary Constituent Standards in well USGS-065.

There were no noncompliance issues associated with the Cold Waste Ponds during the 2015 permit year.
\end{abstract}




\section{CONTENTS}

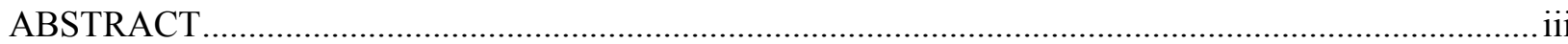

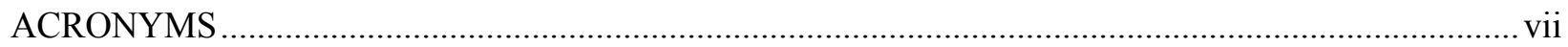

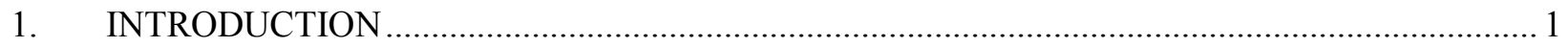

2. FACILITY, SYSTEM DESCRIPTION, AND OPERATION …................................................... 1

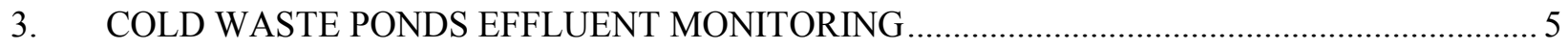

3.1 Sampling Program and Analytical Methods .................................................................... 5

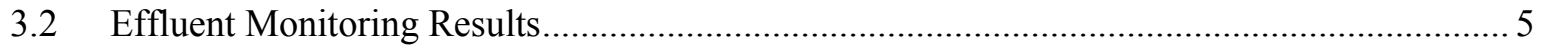

3.3 Flow Volumes and Hydraulic Loading Rates .............................................................. 9

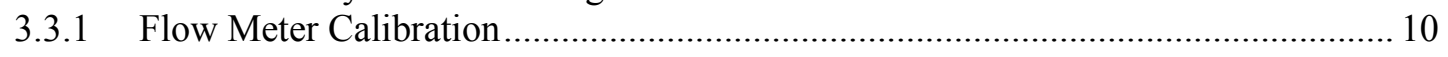

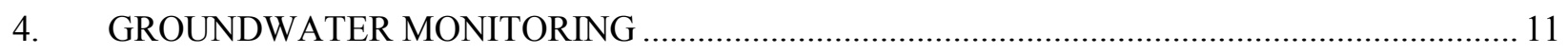

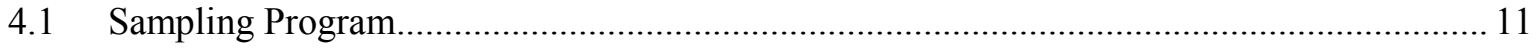

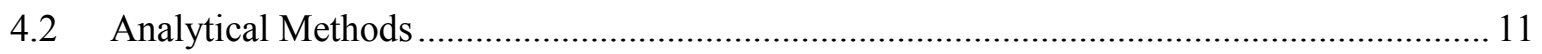

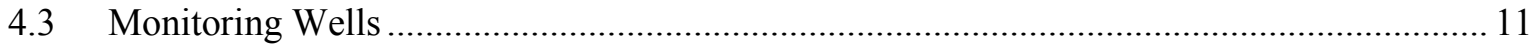

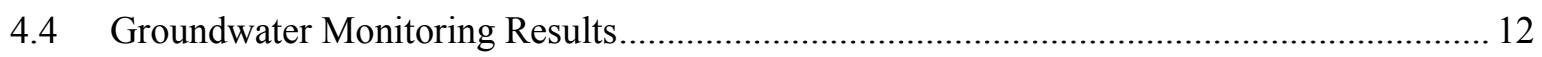

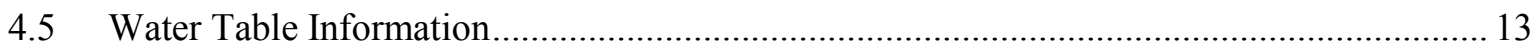

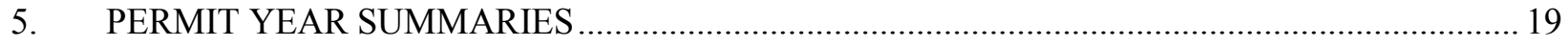

5.1 Status of Permit Required Compliance Activities........................................................... 19

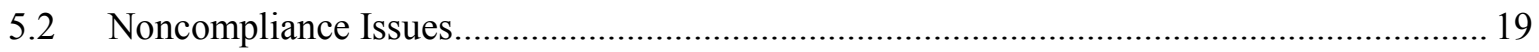

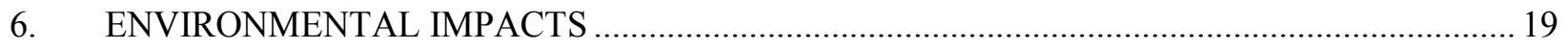

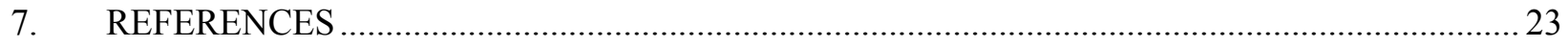

Appendix A Daily Discharge Volumes to the Advanced Test Reactor Complex Cold Waste Ponds 25

\section{FIGURES}

Figure 1. Advanced Test Reactor Complex facility map showing location of the Cold Waste Ponds, monitoring and drinking water wells, Big Lost River, and other associated

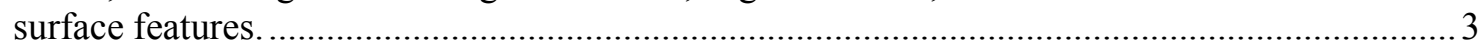

Figure 2. Advanced Test Reactor Complex Cold Waste system flow schematic..................................... 4

Figure 3. Advanced Test Reactor Complex Cold Waste Ponds wastewater 5-year moving average......... 10

Figure 4. Groundwater contour map based on the May 2015 water level measurements. ........................ 17

Figure 5. Groundwater contour map based on the October 2015 water level measurements..................... 18

Figure 6. Sulfate concentrations in the Cold Waste Ponds monitoring wells.......................................... 20 
Figure 7. Total dissolved solids concentrations in the Cold Waste Ponds monitoring wells.

\section{TABLES}

Table 1. Advanced Test Reactor Complex Cold Waste Ponds effluent data (WW-16101) for unfiltered samples collected on November 12, 2014 under permit LA-000161-01, Modification B.

Table 2. Advanced Test Reactor Complex Cold Waste Ponds effluent (WW-16101) data for samples collected in accordance with Reuse Permit I-161-02. 8

Table 3. Cold Waste Ponds flow summaries.

Table 4. Advanced Test Reactor Complex Cold Waste Ponds aquifer monitoring well data for the 2015 reporting year. 15

Table A-1. Daily discharge volumes to the ATR Complex CWP for the 2015 permit year...... 27 


\section{ACRONYMS}

ATR Advanced Test Reactor

$\mathrm{CCN}$ correspondence control number

CFR Code of Federal Regulations

CTS Commitment Tracking System

CWP Cold Waste Pond(s)

DEQ Idaho Department of Environmental Quality

EPA U.S. Environmental Protection Agency

FM flow measurement or monitoring description or identifier

GW prefix for groundwater reporting serial number

IDAPA Idaho Administrative Procedures Act

INL Idaho National Laboratory

IWRP Industrial Wastewater Reuse Permit

MG Million gallons

MS matrix spike

MU prefix for management unit reporting environmental serial number

NA Not Applicable

NAVD North American Vertical Datum

OOS out of service

PCS Primary Constituent Standard

PO Plan of Operation

QAPP Quality Assurance Project Plan

R\&MS Regulatory and Monitoring Services

SCS Secondary Constituent Standard

s.u. standard units for $\mathrm{pH}$

SwRI Southwest Research Institute

TDS total dissolved solids

TKN total Kjeldahl nitrogen

TN total nitrogen

TRA prefix for groundwater reporting (well) common designation number

TSS total suspended solids

USGS prefix for groundwater reporting (well) common designation number

WW prefix for wastewater reporting serial number 


\section{Annual Reuse Report for the Idaho National Laboratory Site's Advanced Test Reactor Complex Cold Waste Ponds}

\section{INTRODUCTION}

The Advanced Test Reactor (ATR) Complex Cold Waste Ponds (CWP) is a reuse facility operated by Battelle Energy Alliance, LLC at Idaho National Laboratory (INL) under Reuse Permit No. I-161-02 issued by the State of Idaho Department of Environmental Quality (DEQ) on November 20, 2014 (Neher 2014a) and expires on November 19, 2019.

The previous permit (LA-000161-01, Modification B) expired on February 25, 2013. However, the Idaho Administrative Procedures Act (IDAPA) 58.01.17.400.10.a (Continuation of Expiring Permits) allows continued coverage under the existing permit provided the permittee submits a timely and sufficient application. A timely and sufficient application is one where the DEQ has determined the application is complete and the applications effective date (date application was determined complete) is prior to the expiration date of the permit. The paragraph below provides the timeline and associated documents to show the application was timely and sufficient.

An application for renewal of the Reuse Permit was submitted to DEQ on August 21, 2012 (Stenzel 2012). The application was determined "substantially complete" with an effective date of October 12 , 2012 (Rackow 2012a). The preliminary decision to prepare a draft permit (Rackow 2012b) was made by DEQ on October 12, 2012. On June 25, 2013, DEQ (Neher 2013) issued a draft Reuse Permit (I-161-02) and a staff analysis for review and comment. Idaho National Laboratory submitted comments to DEQ on the draft permit on July 23, 2013 (Mascareñas 2013). DEQ addressed the comments and issued Draft Permit \#2 on March 26, 2014 (Neher 2014b) for review and comment. Included with Draft Permit \#2 was a new requirement to identify a Responsible Official(s) and Authorized Representative(s), and certify the renewal application. On September 15, 2014 (Miller 2014), INL submitted a comment on the Draft Permit \#2, the applicable DEQ forms for designating a Responsible Official and Authorized Representative, and a certification for the renewal application. As stated above, the final permit was issued on November 20, 2014.

Following the Section 2 CWP facility, system, and operation description, this report presents the effluent and groundwater monitoring data, compliance activities, noncompliances, and environmental impacts of the CWP operation during the 2015 permit year (November 1, 2014-October 31, 2015).

\section{FACILITY, SYSTEM DESCRIPTION, AND OPERATION}

The ATR Complex (Figure 1) is located on approximately 100 acres in the southwestern portion of INL, approximately 47 miles west of Idaho Falls, Idaho, in Butte County. The ATR Complex consists of buildings and structures utilized to conduct research associated with developing, testing, and analyzing materials used in nuclear and reactor applications and both radiological and nonradiological laboratory analyses.

The CWP are located approximately $450 \mathrm{ft}$ from the southeast corner of the ATR Complex compound and approximately $3 / 4$ of a mile northwest of the Big Lost River channel (Figure 1). The existing CWP were excavated in 1982. The CWP consist of two cells, each with dimensions of $180 \times 430 \mathrm{ft}$ across the top of the berms, and a depth of $10 \mathrm{ft}$. Total surface area for the two cells at the top of the berms is approximately 3.55 acres. Maximum capacity is approximately 10,220,000 gal (31.3 acre ft).

Wastewater discharged to the CWP consists primarily of noncontact cooling tower blowdown, once-through cooling water for air conditioning units, coolant water from air compressors, secondary system drains, and other nonradioactive drains throughout the ATR Complex. The wastewater flows 
through collection piping to the TRA-764 Cold Waste Sample Pit (Figure 2) where the flow rate is recorded and compliance monitoring samples are collected. The wastewater then flows to the Cold Waste Sump Pit (TRA-703). The sump pit contains submersible pumps that route the water to the appropriate pond through 8-in. valves.

Wastewater enters the ponds through concrete inlet basins located near the west end. Most of the water percolates into the porous ground within a short distance from the inlet basins. The entire floor of a pond is rarely submerged. If the water level rises significantly in a pond (e.g., $5 \mathrm{ft}$ ), the flow would be diverted to the adjacent pond, allowing the first pond to dry out. An overflow pipe connects the two ponds at the 9-ft level.

Normal operation is to route the wastewater to one pond at a time. Historically, the flow to the ponds was switched annually. Section 4.2 of the Reuse Permit states "DEQ recommends each basin be operated using periods of wetting and drying cycles at set frequencies that provide for both anaerobic and aerobic treatment of the wastewater through the vadose zone."

Beginning in February 2015, the frequency for switching ponds was increased to approximately monthly. The dates when the effluent flow to the ponds were switched can be found in Appendix A. The change in frequency is based on a modeled vadose zone drain-out period for the zone above the shallow perched water zone below the CWP.

There are no existing or planned cross-connections or interconnections between the Cold Waste System wastewater and any water supplies (potable or nonpotable) that would require backflow prevention devices or methods. 


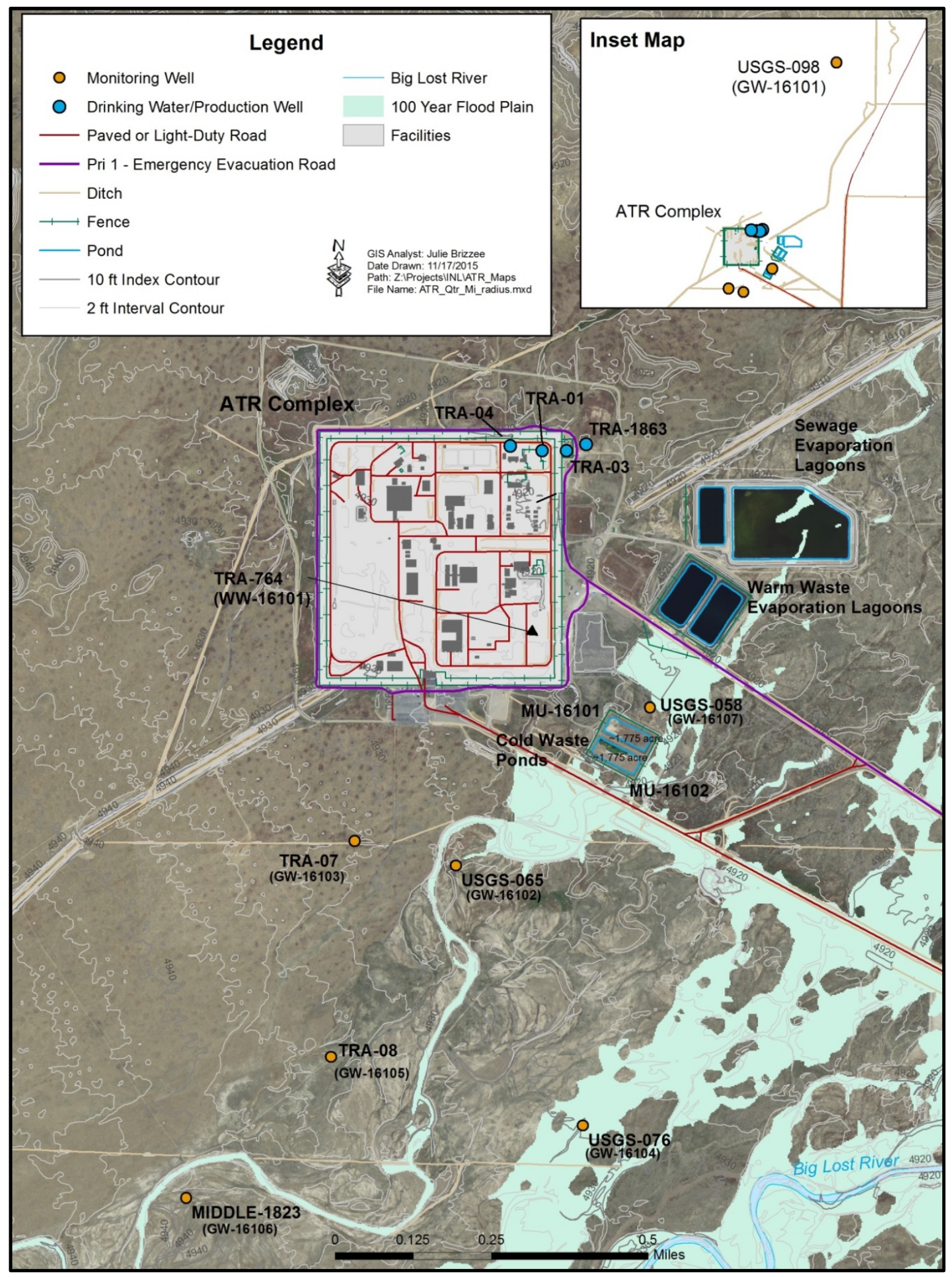

Figure 1. Advanced Test Reactor Complex facility map showing location of the Cold Waste Ponds, monitoring and drinking water wells, Big Lost River, and other associated surface features. 


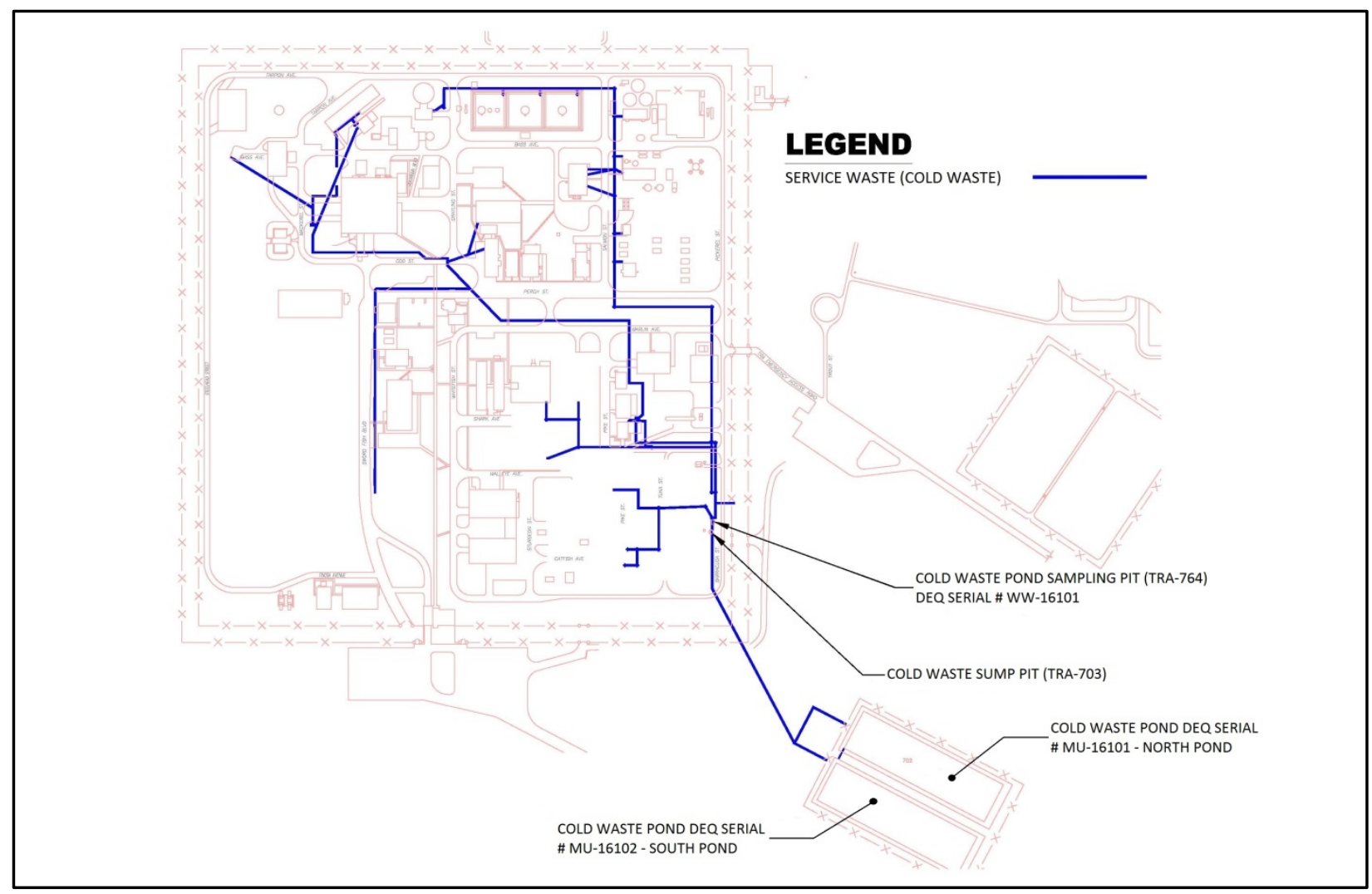

Figure 2. Advanced Test Reactor Complex Cold Waste system flow schematic. 


\section{COLD WASTE PONDS EFFLUENT MONITORING}

This section describes the sampling and analytical methods used in the ATR Complex CWP effluent monitoring program. Effluent monitoring and flow data for wastewater discharged to the ATR Complex CWP are provided.

\subsection{Sampling Program and Analytical Methods}

Battelle Energy Alliance, LLC, Regulatory and Monitoring Services (R\&MS) personnel monitor effluent discharges at the ATR Complex CWP. The R\&MS program involves sampling, analysis, and data interpretation carried out under a quality assurance program. A Quality Assurance Project Plan (QAPP), as required by the Reuse Permit, was submitted to DEQ on May 18, 2015 (Miller 2015a).

The QAPP identifies the scope of monitoring, the organization and individuals involved, data quality objectives, monitoring procedures, and specific quality control measures. The purpose of the QAPP is to ensure data of sufficient quantity and quality are collected to meet permit and regulatory expectations.

Regulatory and Monitoring Services personnel collect monthly effluent sampling as required in Section 5.1.1 of the Reuse Permit. Effluent samples were collected from the TRA-764 Cold Waste Sample Pit (sampling location WW-16101) prior to discharge to the CWP. All samples were collected according to established programmatic sampling procedures. These procedures are now identified in the QAPP.

The monthly effluent sampling schedule at WW-16101 is randomly established at the beginning of each calendar year. The WW-16101 March 2015 sampling evolution, originally scheduled for March 1112, 2015, was rescheduled to March 18-19, 2015, due to maintenance at the TRA-703 pump pit to replace level control switches. Sampling personnel were informed that this maintenance activity included efforts within the ATR Complex to temporarily minimize wastewater generation and the TRA-703 pump pit fill rate, which could result in atypical effluent flows being sampled (i.e., effluent flow could be unusually low during the sampling period or effluent could back up into the sample basin resulting in a nonrepresentative sample). Therefore, the sampling evolution was rescheduled."

Analytical methods specified in 40 Code of Federal Regulations (CFR) 141, "National Primary Drinking Water Regulations"; 40 CFR 143, "National Secondary Drinking Water Regulations," or 40 CFR 136, "Guidelines Establishing Test Procedures for the Analysis of Pollutants" were used for analysis of all permit-required parameters.

Permit required effluent $\mathrm{pH}$ and conductivity analyses are performed at the time of sample collection by R\&MS personnel using a calibrated meter. All other permit-required samples are submitted under full chain of custody to Southwest Research Institute's (SwRI) Analytical and Environmental Chemistry Department located in San Antonio, Texas, for analysis.

\subsection{Effluent Monitoring Results}

The permit year covered in this report is November 1, 2014-October 31, 2015.

Effluent samples were collected monthly from the TRA-764 Cold Waste Sample Pit (prior to discharge to the CWP) during the permit year. Effluent samples were collected as 24-hour flow proportional composite samples.

All samples were collected and analyzed as required by the applicable permit in effect at the time of sampling. Table 1 shows the parameters and sample results required by Industrial Wastewater Reuse Permit (IWRP) LA-000161-01, Modification B. This permit was still in effect at the time the November 2014 compliance samples were collected. 
Table 2 shows the parameters and sample results required by Reuse Permit I-161-02 that became effective on November 20, 2014 and replaced IWRP LA-000161-01, Modification B.

Prior to the issuance of Reuse Permit I-161-02, sampling and analysis required by IWRP LA-00016101, Modification B, demonstrated that some wastewater constituent concentrations were sufficiently low enough or not detected which warranted removal of some parameters from monitoring. Therefore, the DEQ did not require the following parameters to be monitored in the current permit:

- Total metals - arsenic, barium, cadmium, cobalt, copper, iron, manganese, mercury, and silver.

- Inorganics - fluoride, selenium, and total suspended solids (TSS).

The current permit replaced unfiltered aluminum, iron, and manganese parameters with filtered aluminum, iron, and manganese; and also added chromium.

Section F of the previous permit, LA-000161-01, Modification B, specified effluent permit limits based on a 30-day average for total nitrogen (TN) and TSS of $20 \mathrm{mg} / \mathrm{L}$ and $100 \mathrm{mg} / \mathrm{L}$, respectively. Total nitrogen is calculated as the sum of total Kjeldahl nitrogen (TKN) and nitrate plus nitrite nitrogen. The November 2014 sample result for TN was $1.049 \mathrm{mg} / \mathrm{L}$ and below the laboratory instrument detection limit of $4 \mathrm{mg} / \mathrm{L}$ for TSS (Table 1). The current permit does not specify a limit for TN, and TSS was removed as a permit required parameter.

Although, there are no effluent permit limits for total dissolved solids (TDS) or sulfate, a summary comparison of these parameters with the Ground Water Quality Rule Secondary Constituent Standards (SCS) found in IDAPA 58.01.11.200.01.b. is provided below:

The TDS SCS is $500 \mathrm{mg} / \mathrm{L}$. The TDS concentration in the effluent to the CWP ranged from $217 \mathrm{mg} / \mathrm{L}$ in the October 2015 sample to $1,330 \mathrm{mg} / \mathrm{L}$ in the August 2015 sample (Tables 1 and 2). Concentrations of TDS in the effluent were above the SCS level in 3 out of the 12 months.

Similar to the TDS effluent levels, sulfate concentrations were above the SCS of $250 \mathrm{mg} / \mathrm{L}$ in 3 of the 12 monthly samples (Tables 1 and 2). Sulfate ranged from a minimum of $19.8 \mathrm{mg} / \mathrm{L}$ in the September 2015 sample to a maximum of $661 \mathrm{mg} / \mathrm{L}$ in the August 2015 sample.

The ATR evaporative cooling process evaporates approximately one-half of the water volume and concentrates naturally occurring dissolved solids and additives in the blowdown discharged to the CWP. Elevated sulfate levels are generated by reactions between sulfuric acid additives placed in the cooling water and calcium and magnesium carbonates in the water.

The metals concentrations in the CWP effluent remained at low levels (Tables 1 and 2). 
Table 1. Advanced Test Reactor Complex Cold Waste Ponds effluent data (WW-16101) for unfiltered samples collected on November 12, 2014 under permit LA-000161-01, Modification B.

\begin{tabular}{|c|c|c|c|c|}
\hline $\begin{array}{c}\text { Nitrite }+ \text { nitrate as } \\
\text { nitrogen } \\
(\mathrm{mg} / \mathrm{L})\end{array}$ & $\begin{array}{c}\text { Total Kjeldahl } \\
\text { nitrogen } \\
(\mathrm{mg} / \mathrm{L})\end{array}$ & $\begin{array}{l}\text { Total nitrogen } \\
(\mathrm{mg} / \mathrm{L})\end{array}$ & $\begin{array}{c}\text { Total suspended } \\
\text { solids } \\
(\mathrm{mg} / \mathrm{L}) \\
\end{array}$ & $\begin{array}{c}\text { Total dissolved } \\
\text { solids } \\
\text { (mg/L) } \\
\end{array}$ \\
\hline 0.831 & 0.218 & 1.049 & $4.0 \mathrm{U}^{\mathrm{b}}$ & 254 \\
\hline $\begin{array}{c}\text { Chloride } \\
\text { (mg/L) }\end{array}$ & $\begin{array}{c}\text { Electrical } \\
\text { conductivity } \\
(\mu \mathrm{S} / \mathrm{cm})\end{array}$ & $\begin{array}{l}\text { Arsenic } \\
(\mathrm{mg} / \mathrm{L})\end{array}$ & $\begin{array}{l}\text { Barium } \\
(\mathrm{mg} / \mathrm{L})\end{array}$ & $\begin{array}{c}\text { Cadmium } \\
(\mathrm{mg} / \mathrm{L})\end{array}$ \\
\hline $12 \mathrm{~J}^{\mathrm{c}}$ & 424 & $0.005 \mathrm{U}$ & 0.0448 & $0.001 \mathrm{U}$ \\
\hline $\begin{array}{c}\text { Chromium } \\
(\mathrm{mg} / \mathrm{L})\end{array}$ & $\begin{array}{l}\text { Cobalt } \\
(\mathrm{mg} / \mathrm{L})\end{array}$ & $\begin{array}{r}\text { Copper } \\
(\mathrm{mg} / \mathrm{L})\end{array}$ & $\begin{array}{c}\begin{array}{c}\text { Fluoride } \\
(\mathrm{mg} / \mathrm{L})\end{array} \\
\end{array}$ & $\begin{array}{l}\text { Iron } \\
(\mathrm{mg} / \mathrm{L})\end{array}$ \\
\hline 0.00303 & $0.0025 \mathrm{U}$ & 0.00424 & 0.156 & 0.0877 \\
\hline $\begin{array}{c}\text { Manganese } \\
(\mathrm{mg} / \mathrm{L})\end{array}$ & $\begin{array}{l}\text { Mercury } \\
\text { (mg/L) }\end{array}$ & $\begin{array}{c}\text { Selenium } \\
(\mathrm{mg} / \mathrm{L})\end{array}$ & $\begin{array}{l}\text { Silver } \\
(\mathrm{mg} / \mathrm{L})\end{array}$ & $\begin{array}{l}\text { Sulfate } \\
\text { (mg/L) }\end{array}$ \\
\hline $0.0025 \mathrm{U}$ & $0.0002 \mathrm{U}$ & 0.00115 & $0.005 \mathrm{U}$ & 26.8 \\
\hline \multicolumn{5}{|c|}{$\begin{array}{l}\text { a. Total nitrogen is calculated as the sum of the TKN, nitrite nitrogen, and nitrate nitrogen. } \\
\text { b. U flag indicates that the result was reported as below the instrument detection limit by the analytical laboratory. } \\
\text { c. J flag indicates the associated value is detected at the reported concentration, but the reported concentration is an estimate. See Section } 3.2 \text { for } \\
\text { additional discussion. }\end{array}$} \\
\hline
\end{tabular}


Table 2. Advanced Test Reactor Complex Cold Waste Ponds effluent (WW-16101) data for samples collected in accordance with Reuse Permit I161-02.

\begin{tabular}{|c|c|c|c|c|c|c|c|c|c|c|c|}
\hline Sample Month & December & January & February & March & April $^{\mathrm{a}}$ & May & June & July & August & September & October \\
\hline Sample Date & $12 / 11 / 14$ & $01 / 15 / 15$ & $02 / 17 / 15$ & $03 / 19 / 15$ & $04 / 09 / 15$ & $05 / 12 / 15$ & $06 / 11 / 15$ & $07 / 15 / 15$ & $08 / 11 / 15$ & $09 / 02 / 15$ & $10 / 15 / 15$ \\
\hline $\begin{array}{c}\text { Nitrite + nitrate as nitrogen } \\
(\mathrm{mg} / \mathrm{L})\end{array}$ & 0.825 & 0.829 & $0.955 \mathrm{~J}^{\mathrm{b}}$ & 0.815 & $\begin{array}{c}0.822 \\
{[0.83]}\end{array}$ & 0.883 & 2.53 & 2.43 & 3.38 & 0.822 & 0.853 \\
\hline $\begin{array}{c}\text { Total Kjeldahl nitrogen } \\
(\mathrm{mg} / \mathrm{L})\end{array}$ & 0.172 & 0.103 & 0.247 & 0.205 & $\begin{array}{c}0.146 \\
{[0.156]}\end{array}$ & 0.224 & 0.863 & 0.905 & 1.5 & 0.208 & $0.1 \mathrm{U}^{\mathrm{c}}$ \\
\hline Total nitrogen $^{\mathrm{d}}(\mathrm{mg} / \mathrm{L})$ & 0.997 & 0.932 & 1.202 & 1.02 & $\begin{array}{c}0.968 \\
{[0.986]}\end{array}$ & 1.107 & 3.393 & 3.335 & 4.88 & 1.03 & $<0.953$ \\
\hline $\mathrm{pH}$ (s.u.) & 7.72 & 7.4 & 7.46 & 6.89 & 7.64 & 8.24 & 7.89 & 7.9 & 7.93 & 8.08 & 8.11 \\
\hline $\begin{array}{c}\text { Electrical conductivity } \\
(\mu \mathrm{S} / \mathrm{cm})\end{array}$ & 418 & 475 & 537 & 459 & 487 & 424 & 1,158 & 1,331 & 1,727 & 449 & 430 \\
\hline Chloride (mg/L) & $11.9 \mathrm{~J}$ & 12.5 & 12.1 & 9.8 & $\begin{array}{c}10.5 \\
{[10.1]} \\
\end{array}$ & 11.7 & 34.1 & 31.6 & 57.7 & 10.3 & 10.6 \\
\hline Sulfate $(\mathrm{mg} / \mathrm{L})$ & 24.6 & 27.3 & $49.3 \mathrm{~J}$ & 20.9 & $\begin{array}{c}20.7 \\
{[20.8]}\end{array}$ & 30.4 & 410 & 402 & 661 & 19.8 & 21.2 \\
\hline Total dissolved solids (mg/L) & 233 & 245 & 278 & 242 & $\begin{array}{c}239 \\
{[248]}\end{array}$ & 262 & 899 & 909 & 1,330 & 221 & 217 \\
\hline Aluminum, filtered (mg/L) & $0.025 \mathrm{U}$ & $0.025 \mathrm{U}$ & $0.025 \mathrm{U}$ & $0.025 \mathrm{U}$ & $\begin{array}{c}0.025 \mathrm{U} \\
{[0.025 \mathrm{U}]} \\
\end{array}$ & $0.025 \mathrm{U}$ & $0.025 \mathrm{U}$ & $0.025 \mathrm{U}$ & $0.025 \mathrm{U}$ & $0.025 \mathrm{U}$ & $0.025 \mathrm{U}$ \\
\hline Chromium, total (mg/L) & 0.00281 & 0.00289 & 0.00402 & 0.00357 & $\begin{array}{c}0.00417 \\
{[0.00414]}\end{array}$ & 0.00306 & 0.0105 & 0.0081 & 0.0124 & 0.00369 & 0.0035 \\
\hline Chromium, filtered (mg/L) & 0.00303 & 0.00285 & 0.00477 & 0.00292 & $\begin{array}{c}0.00411 \\
{[0.00414]}\end{array}$ & 0.0028 & 0.0113 & 0.00773 & 0.0121 & 0.00355 & 0.00356 \\
\hline Iron, filtered (mg/L) & 0.0553 & 0.0443 & $0.025 \mathrm{U}$ & $0.025 \mathrm{U}$ & $\begin{array}{c}0.0646 \\
{[0.0705]}\end{array}$ & $0.025 \mathrm{U}$ & 0.217 & $0.025 \mathrm{U}$ & $0.025 \mathrm{U}$ & $0.025 \mathrm{U}$ & $0.025 \mathrm{U}$ \\
\hline Manganese, filtered (mg/L) & $0.0025 \mathrm{U}$ & $0.0025 \mathrm{U}$ & $0.0025 \mathrm{U}$ & $0.0025 \mathrm{U}$ & $\begin{array}{c}0.0025 \mathrm{U} \\
{[0.0025 \mathrm{U}]}\end{array}$ & $0.0025 \mathrm{U}$ & 0.00822 & $0.0025 \mathrm{U}$ & 0.0042 & $0.0025 \mathrm{U}$ & $0.0025 \mathrm{U}$ \\
\hline \multicolumn{12}{|c|}{$\begin{array}{l}\text { a. Results shown in brackets are from field duplicate samples. } \\
\text { b. J flag indicates the associated value is detected at the reported concentration, but the reported concentration is an estimate. See Section } 3.2 \text { for additional discussion. } \\
\text { c. U flag indicates that the result was reported as below the instrument detection limit by the analytical laboratory. } \\
\text { d. Total nitrogen is calculated as the sum of the TKN, nitrite nitrogen, and nitrate nitrogen. For results reported below the instrument detection limit, the detection limit for that } \\
\text { parameter is used in the calculation. The resulting total nitrogen is then reported as a less than }(<) \text { number. }\end{array}$} \\
\hline
\end{tabular}


Several effluent sample results were qualified during data validation. Although the reported concentrations may be considered questionable, inaccurate, or imprecise, the estimated values are provided in Tables 1 and 2. These qualified data are discussed below:

- The chloride results for samples collected on November 12, 2014, and December 11, 2014, were assigned a $\mathrm{J}$ flag because of low matrix spike (MS) recovery. A MS is an aliquot of a field sample that has been fortified (spiked) with known quantities of pertinent analytes before being processed in an identical manner as is required for the unspiked version of the same field sample. The MS result for chloride was $82.5 \%$ and was outside the $90-110 \%$ acceptance criteria per U.S. EPA Method 300 and Inorganic Analyses Data Validation for INL (GDE-8511), section 4.3.9.5.4. The J flag denotes the data is detected at the reported concentration, but the reported concentration is an estimate due to low MS recovery.

- The nitrate+nitrite as nitrogen sample collected on February 17, 2015, was qualified with a $\mathrm{J}$ flag during data validation because the sample was above the instrument detection level but exceeded the 48-hour holding time. Holding time is the time between sample collection and sample analysis. The $\mathrm{J}$ flag denotes the data is detected at the reported concentration, but the reported concentration is an estimate due to the exceeded holding time.

- The February 17,2015 , sulfate sample result was J flagged during data validation. The sulfate sample result was above the instrument detection level but outside the MS 90-110\% acceptance criteria per U.S. EPA Method 300 and Inorganic Analyses Data Validation for INL (GDE-8511), section 4.3.9.5.4 at 87\%. The J flag for the February 17, 2015, sulfate sample denotes the data is detected at the reported concentration, but the reported concentration is an estimate due to low MS recovery.

\subsection{Flow Volumes and Hydraulic Loading Rates}

Daily flow readings were taken by ATR Complex CWP Operations during the 2015 permit year, as required by Section 5.1.2 of the Reuse Permit, at the TRA-764 Cold Waste Sample Pit where the flow meter (FM-16101) is located. The flow meter measures flow to the North Pond (MU-16101) and to the South Pond (MU-16102). All flow readings were recorded in gallons per day.

Table 3 summarizes monthly and annual flow data. Daily effluent flow data is provided in Appendix A.

Table 3. Cold Waste Ponds flow summaries.

\begin{tabular}{|c|c|c|c|}
\hline Month & $\begin{array}{c}\text { North Pond } \\
\text { (MU-16101) } \\
(\mathbf{M G )}\end{array}$ & $\begin{array}{c}\text { South Pond } \\
\text { (MU-16102) } \\
\text { (MG) }\end{array}$ & $\begin{array}{c}\text { Monthly Total for } \\
\text { Both Ponds } \\
\text { (MG) }\end{array}$ \\
\hline November 2014 & 0.00 & 23.93 & 23.93 \\
\hline December 2014 & 0.00 & 24.85 & 24.85 \\
\hline January 2015 & 0.00 & 25.16 & 25.16 \\
\hline February 2015 & 20.55 & 0.92 & 21.47 \\
\hline March 2015 & 8.15 & 9.80 & 17.95 \\
\hline April 2015 & 12.66 & 0.92 & 13.58 \\
\hline May 2015 & 0.00 & 20.91 & 20.91 \\
\hline June 2015 & 0.00 & 12.84 & 12.84 \\
\hline July 2015 & 15.86 & 0.00 & 15.86 \\
\hline August 2015 & 0.00 & 16.45 & 16.45 \\
\hline
\end{tabular}




\begin{tabular}{|c|c|c|c|}
\hline Month & $\begin{array}{c}\text { North Pond } \\
(\mathrm{MU}-16101) \\
(\mathrm{MG})^{\mathrm{a}}\end{array}$ & $\begin{array}{c}\text { South Pond } \\
\text { (MU-16102) } \\
\text { (MG) }\end{array}$ & $\begin{array}{c}\text { Monthly Total for } \\
\text { Both Ponds } \\
\text { (MG) }\end{array}$ \\
\hline September 2015 & 16.77 & 0.67 & 17.44 \\
\hline October 2015 & 0.00 & 17.63 & 17.63 \\
\hline Annual Total & 73.99 & 154.09 & 228.08 \\
\hline
\end{tabular}

Section 4.2 of the permit requires that the total annual volume discharged to the North and South Ponds shall not exceed a 5-year moving annual average of 300 million gallons (MG)/year. No single year shall exceed $375 \mathrm{MG} / \mathrm{yr}$. Annual hydraulic loading data from previous reporting years under IWRP LA000161-01 are used to determine compliance with the moving annual average. Flow recording became a permit requirement when IWRP LA000161-01 was issued on February 26, 2008. Because permit year 2008 was only a partial year, data from permit year 2009 and subsequent years was used to calculate the 5 -year moving average (Figure 3).

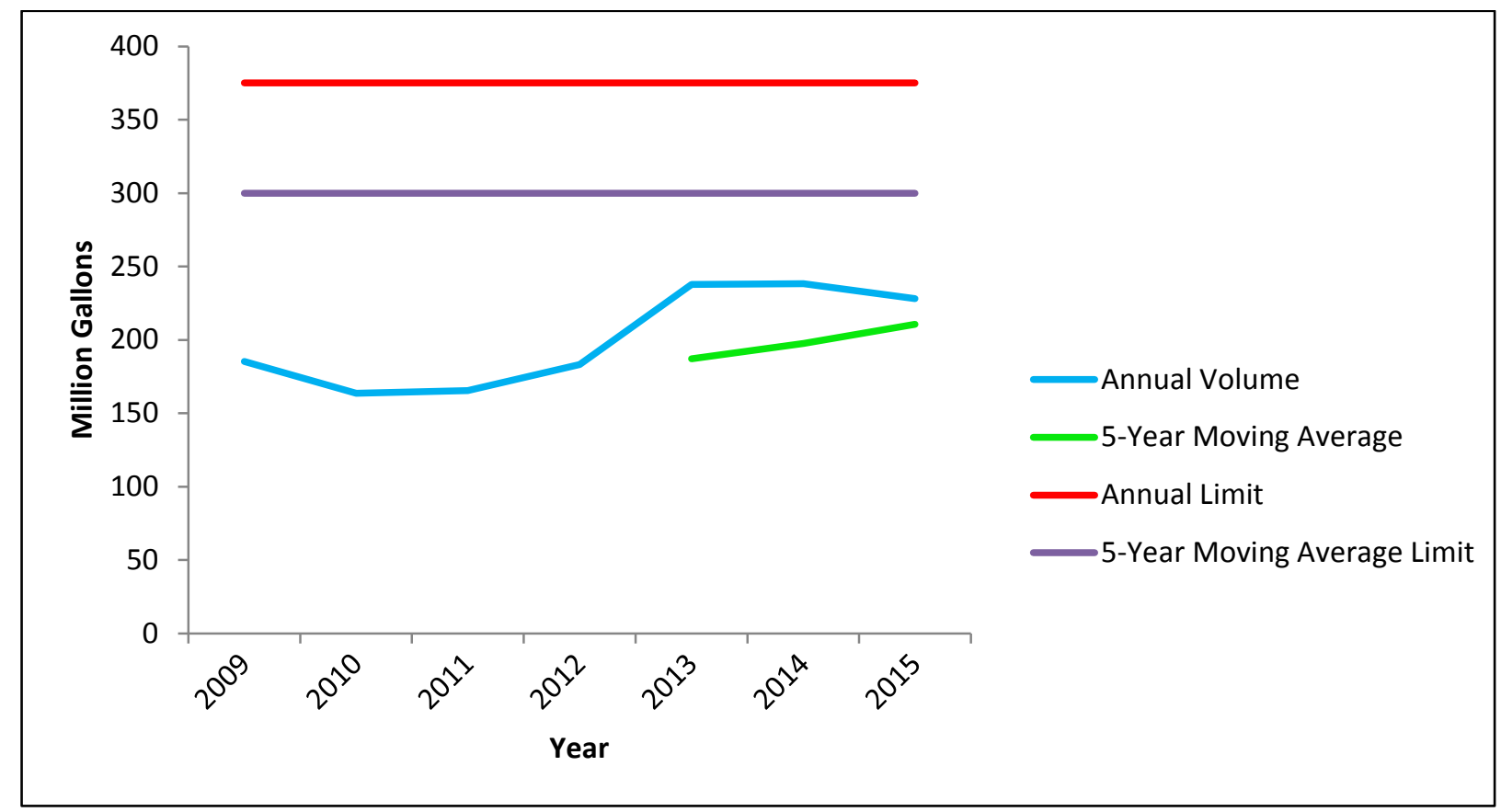

Figure 3. Advanced Test Reactor Complex Cold Waste Ponds wastewater 5-year moving average.

For permit year 2015, the total volume discharged to the North and South ponds was $73.99 \mathrm{MG}$ and 154.09 MG, respectively. The total annual volume discharged to both ponds was $228.08 \mathrm{MG}$ and significantly less than the maximum Reuse Permit annual limit of 375 MG.

\subsubsection{Flow Meter Calibration}

Prior to the issuance of the current Reuse Permit on November 20, 2014, Section G of IWRP No. LA000161-01 Modification B issued on February 26, 2008, required annual calibration of all flow meters and pumps used directly or indirectly to measure all wastewater applied to the CWP. The IWRP was in effect for 19 days during report year 2015 before the current Reuse Permit was issued. However, a previous calibration during report year 2014 was performed on May 27, 2014, and therefore not due during the remainder of the time the IWRP was in effect. 
Calibration is performed annually and was performed on June 15, 2015, by the ATR Complex maintenance organization. The calibrations were performed to $+/-2 \%$ of full scale (full scale $=1400$ gpm). The as found calibration of the flow meter was determined to be satisfactory."

\section{GROUNDWATER MONITORING}

The groundwater monitoring sections provide information concerning the INL sampling program, analytical methods used, and monitoring results, and water table information.

\subsection{Sampling Program}

The ATR Complex CWP Reuse Permit identifies six INL compliance wells. The permit requires that groundwater samples be collected from these six compliance wells semiannually in April or May and September or October.

The R\&MS personnel collected groundwater samples in May and October 2015. The R\&MS personnel use project-specific sampling and analysis plans and procedures that govern sampling activities and quality control protocols. The October 2015 sampling was conducted in accordance with the QAPP that was submitted to DEQ on May 18, 2015 (Miller 2015a). The permit identifies a specified list of parameters that are to be analyzed in the groundwater samples. Constituent concentrations in the compliance wells are limited by primary constituent standards (PCS) and SCS specified in IDAPA 58.01.11, "Ground Water Quality Rule" with the exception of chromium. In accordance with Reuse Permit, Section 5.2.2, footnote a., "compliance with the Primary Constituent Standard for Chromium, under this permit, shall not apply."

As required by the Reuse Permit, unfiltered samples were collected and analyzed for nitrate + nitrite, as nitrogen, TKN, TDS, $\mathrm{pH}$, electrical conductivity, chloride, chromium, and sulfate. Filtered samples were collected and analyzed for aluminum, chromium, iron, and manganese.

Groundwater $\mathrm{pH}$ and conductivity analyses are performed at the time of sample collection by R\&MS personnel using a calibrated meter(s). All other permit required groundwater samples are submitted under full chain of custody to SwRI's Analytical and Environmental Chemistry Department located in San Antonio, Texas, for analysis.

\subsection{Analytical Methods}

Analytical methods specified in 40 CFR 141, "National Primary Drinking Water Regulations"; 40 CFR 143, "National Secondary Drinking Water Regulations" or 40 CFR 136, "Guidelines Establishing Test Procedures for the Analysis of Pollutants" were used for analysis of all permit-required parameters.

\subsection{Monitoring Wells}

To measure potential impacts to groundwater from the ATR Complex CWP, the permit requires that groundwater samples be collected from six monitoring wells located in the Snake River Plain Aquifer (Figure 1):

- USGS-098 (GW-16101)

- USGS-065 (GW-16102)

- USGS-076 (GW-16104)

- TRA-08 (GW-16105)

- Middle-1823 (GW-16106)

- USGS-058 (GW-16107).

All six wells are Reuse Permit compliance points. Wells with sufficient water volume are purged to a minimum of three casing volumes or one well volume with three successive field measurements, taken 
not less than one minute apart, for $\mathrm{pH}$, conductivity, and temperature and meet the following conditions: temperature must be within $1^{\circ} \mathrm{C}$ of each other, and conductivity values must be within $10 \%$ of each other (LI-330).

Groundwater monitoring well TRA-07 (GW-16103) was required under the previous permit as a compliance point monitoring well. However, under the current Reuse Permit Section 5.2.1 "Ground Water Monitoring Point Descriptions" table references TRA-07 in the table's footnotes as "not required under this permit". Therefore, no samples or water level information were obtained from this well.

\subsection{Groundwater Monitoring Results}

Table 4 shows the 2015 reporting year water table elevations and depth to water table, determined prior to purging and sampling, and the analytical results for all parameters specified by the permit for the six aquifer wells. For well USGS-058, the Reuse Permit only requires sampling, analysis, and reporting of TDS and sulfate.

With the exception of upgradient monitoring well USGS-098, the permit-required parameters were below their respective Ground Water Quality Rule (IDAPA 58.01.11) PCSs or SCSs during the 2015 reporting year for all six wells. The May 6, 2015, chromium sample concentration in well USGS-098 was $0.149 \mathrm{mg} / \mathrm{L}$ in the unfiltered sample and above the chromium PCS of $0.1 \mathrm{mg} / \mathrm{L}$. No issues were identified by the laboratory or during data validation. The chromium concentration in the unfiltered sample collected on October 13, 2015, from USGS-098 was $0.0064 \mathrm{mg} / \mathrm{L}$ and significantly lower than the PCS and May 6, 2015, sample result. The May chromium sample concentration may have been an anomaly. As previously discussed in Section 4.1, compliance with the chromium PCS is not applicable under the current Reuse Permit and therefore, the high chromium sample result is not a violation of the Reuse Permit requirements.

Chromium concentrations in the filtered and unfiltered samples from the other four monitoring wells were all significantly lower than the PCS.

Aluminum, iron, and manganese concentrations in the filtered samples from all five wells were significantly lower than their respective SCS. Filtered iron and manganese concentrations in the five monitoring wells were typically below the laboratory instrument minimum detection limits or just slightly above.

Monitoring well USGS-065 is a downgradient well located southwest of the CWP. Sulfate and TDS concentrations in this well are consistently high but less than the applicable sulfate and TDS SCS of 250 $\mathrm{mg} / \mathrm{L}$ and $500 \mathrm{mg} / \mathrm{L}$, respectively. Sulfate concentration was highest in the October 14, 2015, sample at $157 \mathrm{mg} / \mathrm{L}$. The highest TDS concentration for this well occurred in the May sample at $429 \mathrm{mg} / \mathrm{L}$.

Sulfate and TDS concentrations in the other five wells, including USGS-058, were significantly lower than those in well USGS-065. Well USGS-058, slightly upgradient of the North Pond, showed sulfate and TDS concentrations similar to well Middle-1823 which is the downgradient well located farthest from the CWP.

A few groundwater sample results were qualified during data validation. Although the reported concentrations may be considered questionable, inaccurate, or imprecise, the estimated values are provided in Table 4. These qualified data are discussed below:

- All May 2015 groundwater chloride results (Table 4) were assigned a J flag because of low MS recovery. The MS result for chloride was $87.5 \%$ and was outside the $90-110 \%$ acceptance criteria per U.S. EPA Method 300. The J flag denotes the data is detected at the reported concentration, but the reported concentration is an estimate due to low MS recovery. 
- For well USGS-065, the May 7, 2015, sample result for nitrite + nitrate as nitrogen (Table 4) was assigned a $\mathrm{J}$ flag because the required 48 -hour hold time was exceeded. The actual hold time was approximately 121 hours. The $\mathrm{J}$ flag denotes the data is detected at the reported concentration, but the reported concentration is an estimate due to the exceeded holding time.

\subsection{Water Table Information}

Depth to water and water table elevations for the May and October sampling events are shown in Figure 4 and Figure 5, respectively. The elevations are presented in North American Vertical Datum of 1988 (NAVD 88). In addition, the figures show the inferred general groundwater flow direction in the vicinity of the ATR Complex. In this area, the flow is in a south to southwest direction. The general groundwater flow direction at the INL Site is to the southwest. 
Table 4. Advanced Test Reactor Complex Cold Waste Ponds aquifer monitoring well data for the 2015 reporting year.

\begin{tabular}{|c|c|c|c|c|c|c|c|c|c|c|c|c|c|}
\hline \multirow{2}{*}{$\begin{array}{c}\text { WELL NAME } \\
\text { Sample Date } \\
\end{array}$} & \multicolumn{2}{|c|}{$\begin{array}{l}\text { USGS-098 } \\
\text { (GW-16101) }\end{array}$} & \multicolumn{2}{|c|}{$\begin{array}{c}\text { USGS-065 } \\
\text { (GW-16102) }\end{array}$} & \multicolumn{2}{|c|}{$\begin{array}{l}\text { USGS-076 } \\
\text { (GW-16104) }\end{array}$} & \multicolumn{2}{|c|}{$\begin{array}{c}\text { TRA-08 } \\
\text { (GW-16105) }\end{array}$} & \multicolumn{2}{|c|}{$\begin{array}{l}\text { Middle-1823 } \\
\text { (GW-16106) }\end{array}$} & \multicolumn{2}{|c|}{$\begin{array}{c}\text { USGS-058 } \\
\text { (GW-16107) }\end{array}$} & \multirow{2}{*}{$\mathbf{P C S} / \mathbf{S C S}^{\mathrm{a}}$} \\
\hline & $05 / 06 / 15$ & $10 / 13 / 15$ & $05 / 07 / 15$ & $10 / 14 / 15$ & $05 / 06 / 15$ & $10 / 13 / 15$ & $05 / 07 / 15$ & $10 / 14 / 15$ & $05 / 06 / 15$ & $10 / 13 / 15$ & $05 / 07 / 15$ & $10 / 14 / 15$ & \\
\hline $\begin{array}{c}\text { Water Table Depth } \\
\text { (ft below ground surface) }\end{array}$ & 426.66 & 427.54 & 475.91 & 477.19 & 484.45 & 485.51 & 489.77 & 490.83 & 494.16 & 495.32 & 472.51 & 473.5 & $\mathrm{NA}^{\mathrm{b}}$ \\
\hline $\begin{array}{l}\text { Water Table Elevation } \\
\text { (above mean sea level in ff) }^{\mathrm{c}}\end{array}$ & 4460.2 & 4459.32 & 4452.61 & 4451.33 & 4448.76 & 4447.7 & 4448.66 & 4447.6 & 4448.71 & 4447.55 & 4449.38 & 4448.39 & NA \\
\hline 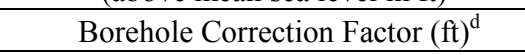 & 2.58 & 2.58 & NA & NA & NA & NA & 0.63 & 0.63 & NA & NA & $\mathrm{NA}$ & NA & $\mathrm{NA}$ \\
\hline Nitrite + nitrate as nitrogen $(\mathrm{mg} / \mathrm{L})$ & 0.99 & 0.96 & $1.46 \mathrm{~J}^{\mathrm{e}}$ & 1.44 & 1 & 0.994 & 0.915 & 0.964 & 0.969 & $\begin{array}{c}0.934 \\
{[0.947]^{\mathrm{f}}}\end{array}$ & $\mathrm{NR}^{\mathrm{g}}$ & NR & NA \\
\hline Total Kjeldahl nitrogen $(\mathrm{mg} / \mathrm{L})$ & 0.165 & $0.1 \mathrm{U}^{\mathrm{h}}$ & 0.136 & 0.193 & 0.432 & 0.19 & 0.172 & 0.193 & 0.182 & $\begin{array}{c}0.167 \\
{[0.171]}\end{array}$ & NR & NR & NA \\
\hline Total nitrogen $(\mathrm{mg} / \mathrm{L})$ & 1.155 & $<1.06$ & 1.596 & 1.633 & 1.432 & 1.184 & 1.087 & 1.157 & 1.151 & $\begin{array}{c}1.101 \\
{[1.118]}\end{array}$ & NR & NR & NA \\
\hline pH (s.u.) & 8.15 & 8.01 & 8.15 & 8 & 8.13 & 7.9 & 8.33 & 8.1 & 8.12 & 7.96 & NR & NR & 6.5 to 8.5 \\
\hline Electrical conductivity $(\mu \mathrm{S} / \mathrm{cm})$ & 384 & 409 & 594 & 604 & 426 & 414 & 424 & 435 & 418 & 435 & NR & $\mathrm{NR}$ & NA \\
\hline Chloride $(\mathrm{mg} / \mathrm{L})$ & $14.2 \mathrm{~J}$ & 14.9 & $19.3 \mathrm{~J}$ & 19.8 & $13.1 \mathrm{~J}$ & 13.4 & $11.7 \mathrm{~J}$ & 12.3 & $11.6 \mathrm{~J}$ & $\begin{array}{c}11.8 \\
{[11.8]}\end{array}$ & $\mathrm{NR}$ & $\mathrm{NR}$ & $\begin{array}{l}250 \\
\text { (SCS) }\end{array}$ \\
\hline Sulfate $(\mathrm{mg} / \mathrm{L})$ & 21.6 & 21.4 & 145 & 157 & 34.2 & 35.3 & 43.4 & 47.7 & 35 & $\begin{array}{c}35.6 \\
{[35.6]}\end{array}$ & 34.4 & 34.9 & $\begin{array}{l}250 \\
(\mathrm{SCS})\end{array}$ \\
\hline Total dissolved solids (mg/L) & 236 & 222 & 429 & 401 & 272 & 248 & 263 & 252 & 276 & $\begin{array}{c}242 \\
{[246]}\end{array}$ & 269 & 245 & $\begin{array}{l}500 \\
(\mathrm{SCS})\end{array}$ \\
\hline Aluminum, filtered $(\mathrm{mg} / \mathrm{L})$ & 0.00389 & $0.005 \mathrm{U}$ & 0.0079 & 0.0163 & 0.00671 & 0.00752 & 0.0154 & 0.0093 & 0.00431 & $\begin{array}{c}0.00555 \\
{[0.00511]} \\
\end{array}$ & NR & NR & $\begin{array}{c}0.2 \\
(\mathrm{SCS})\end{array}$ \\
\hline Chromium', total (mg/L) & 0.149 & 0.0064 & 0.0706 & 0.0733 & 0.0108 & 0.0105 & 0.082 & 0.0345 & 0.0117 & $\begin{array}{c}0.00923 \\
{[0.00957]}\end{array}$ & $\mathrm{NR}$ & NR & $\begin{array}{c}0.1 \\
(\mathrm{PCS})\end{array}$ \\
\hline Chromium', filtered (mg/L) & $0.0025 \mathrm{U}$ & 0.00544 & 0.0704 & 0.0729 & 0.00982 & 0.0105 & 0.0155 & 0.0175 & 0.00963 & $\begin{array}{c}0.00950 \\
{[0.00964]}\end{array}$ & NR & NR & $\begin{array}{c}0.1 \\
(\mathrm{PCS})\end{array}$ \\
\hline Iron, filtered $(\mathrm{mg} / \mathrm{L})$ & $0.050 \mathrm{U}$ & 0.0578 & $0.050 \mathrm{U}$ & 0.0611 & $0.050 \mathrm{U}$ & 0.0544 & $0.050 \mathrm{U}$ & 0.0558 & $0.050 \mathrm{U}$ & $\begin{array}{l}0.050 \mathrm{U} \\
{[0.0556]}\end{array}$ & NR & NR & $\begin{array}{c}0.3 \\
(\mathrm{SCS})\end{array}$ \\
\hline Manganese, filtered (mg/L) & 0.00785 & $0.0025 \mathrm{U}$ & $0.0025 \mathrm{U}$ & $0.0025 \mathrm{U}$ & $0.0025 \mathrm{U}$ & $0.0025 \mathrm{U}$ & $0.0025 \mathrm{U}$ & $0.0025 \mathrm{U}$ & $0.0025 \mathrm{U}$ & $\begin{array}{c}0.0025 \mathrm{U} \\
{[0.0025 \mathrm{U}]}\end{array}$ & NR & NR & $\begin{array}{l}0.05 \\
(\mathrm{SCS})\end{array}$ \\
\hline $\begin{array}{l}\text { a. Primary constituent standards (PCS) and sec } \\
\text { b. NA- Not applicable. } \\
\text { c. Elevation data provided using the North Am } \\
\text { d. The United States Geological Survey perfor } \\
\text { table. The water table elevations for these two } \\
\text { e. flag indicates the associated value is an est } \\
\text { f. Results shown in brackets are the results fro } \\
\text { g. NR indicates the parameter is not required b }\end{array}$ & $\begin{array}{l}\text { ortical atur } \\
\text { ocseope surv } \\
\text { ve been adju } \\
\text { d may be in } \\
\text { luplicate sam } \\
\text { use Permit. } \\
\text { v the instrum } \\
\text { itritite nitroge }\end{array}$ & $\begin{array}{l}\text { or imprecise. } \\
\text { of }\end{array}$ & on 4.4 for ac & $\begin{array}{l}\text { 5. The usurey y } \\
\text { termined fro } \\
\text { iscussion. }\end{array}$ & $\begin{array}{l}\text { enese tiov } \\
\text { copic sur }\end{array}$ & t perfectlly & vertical w & se the wat & surements & ter than the t & from the & oint on th & the water \\
\hline
\end{tabular}





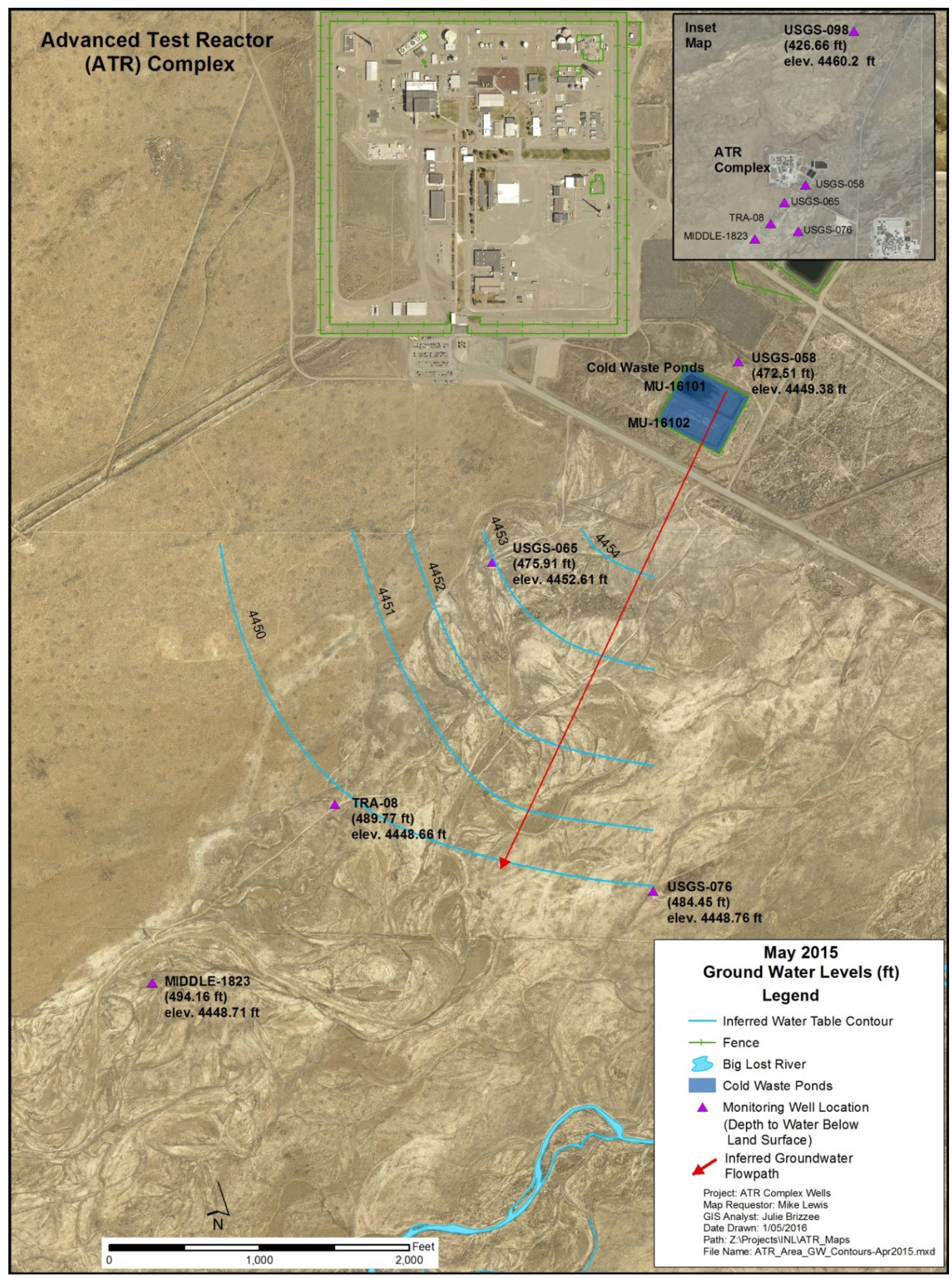

Figure 4. Groundwater contour map based on the May 2015 water level measurements. 


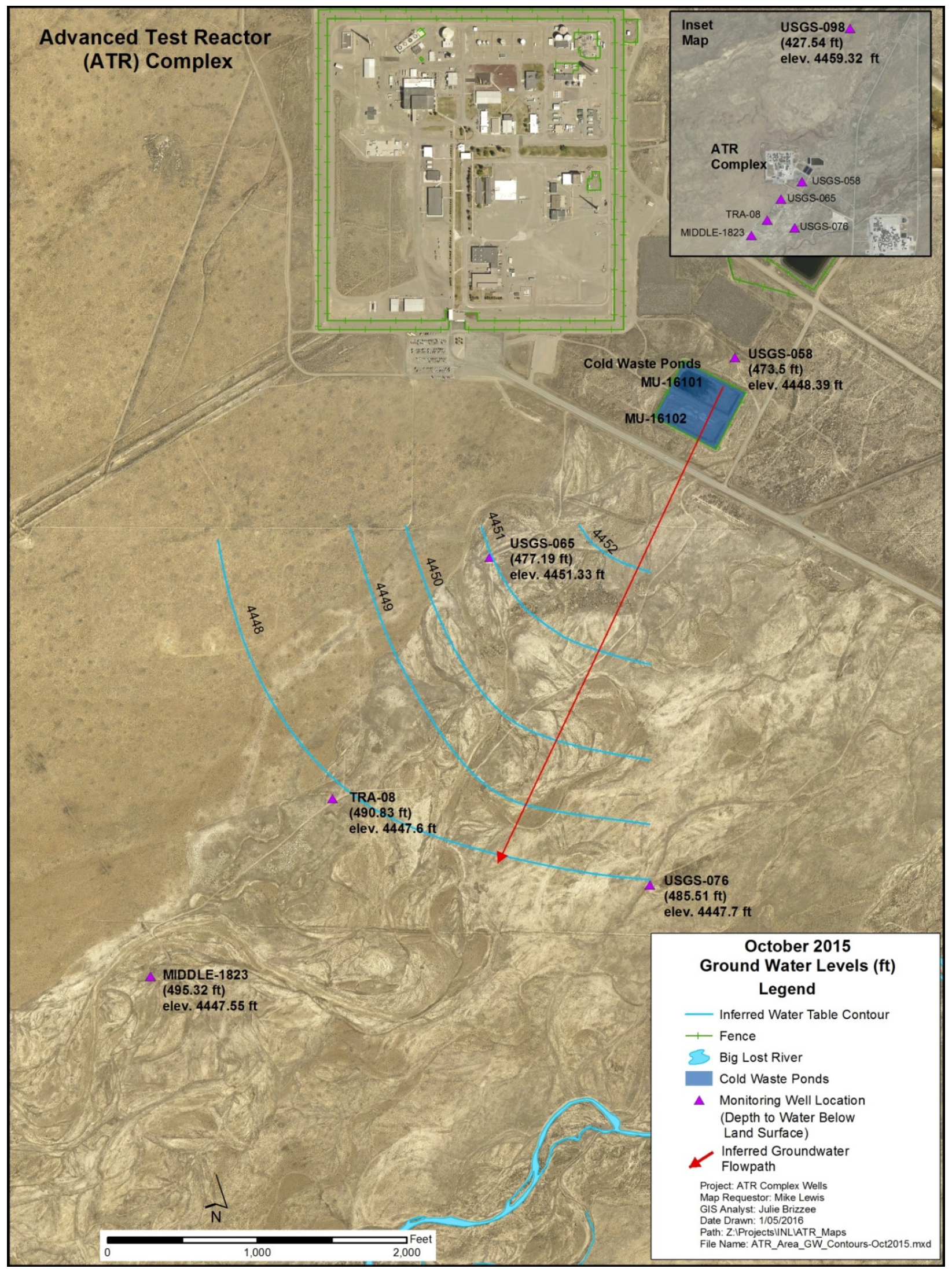

Figure 5. Groundwater contour map based on the October 2015 water level measurements. 


\section{PERMIT YEAR SUMMARIES}

This section provides information and status associated with permit required compliance activities and noncompliance issues.

\subsection{Status of Permit Required Compliance Activities}

Section 3 of the Reuse Permit identifies four compliance activities (CA-161-01 through 04) discussed below:

CA-161-01 - Within 12 months of permit issuance, the permittee shall submit for review and approval a Plan of Operation (PO) that reflects current operations and incorporates the requirements of the Reuse Permit. The PO shall be updated as needed to reflect current operations. The permittee shall notify DEQ of material changes to the PO and copies shall be kept on site and made available to DEQ upon request.

The PO was submitted to DEQ on November 19, 2015 (Miller 2015b). Approval of the PO from DEQ has not been received.

CA-161-02 - Within 6 months of permit issuance, the permittee is required to prepare and implement a Quality Assurance Project Plan (QAPP) that incorporates all monitoring and reporting required by the permit. A copy of the QAPP and a written notice that the QAPP has been implemented shall be provided to DEQ.

A copy of the QAPP and the implementation notice were submitted to DEQ on May 18, 2015 (Miller 2015a).

CA-161-03 - Twelve months prior to permit expiration, the permittee shall contact DEQ and schedule a pre-application workshop to discuss the compliance status of the facility and the content required for the reuse permit application package.

This requirement has been added to the INL electronic Commitment Tracking System (CTS). This system provides automatic reminders to those responsible for completing the action. The first reminder date for this activity is May 18, 2018.

CA-161-04 - Six months prior to permit expiration the permittee shall submit to DEQ a complete permit renewal application package, which fulfills the requirements specified at the pre-application workshop identified in CA-161-03.

The first CTS reminder date for this activity is also May 18, 2018.

\subsection{Noncompliance Issues}

There were no permit noncompliance issues for the 2015 reporting year.

\section{ENVIRONMENTAL IMPACTS}

The Reuse Permit allows $300 \mathrm{MG} /$ year as a 5-year annual average, not to exceed $375 \mathrm{MG}$ annually. The total volume discharged to the CWP for this period (November 1, 2014-October 31, 2015) was 228.08 MG. No runoff occurred from the application area.

High-effluent concentrations of TSS have the potential to reduce the infiltration capacity of the soil. Historical concentrations of TSS have been at or near the laboratory instrument minimum detection level of $4 \mathrm{mg} / \mathrm{L}$. Because of the consistently low levels of TSS in the effluent discharged to the CWP, the requirement to monitor this parameter was removed from the current Reuse Permit. Table 1 shows the November 2014 TSS sample result required by the previous permit as undetected at $4 \mathrm{mg} / \mathrm{L}$. No negative impacts to the soil infiltration capacity from typical TSS loading are expected. 
Total nitrogen concentrations in the effluent ranged between $0.932 \mathrm{mg} / \mathrm{L}$ in the October 2015 sample to $4.88 \mathrm{mg} / \mathrm{L}$ in the August 2015 sample (Tables 1 and 2). Nitrogen can be lost or removed from the soil by leaching, ammonia volatilization, and denitrification. Total nitrogen in the nearest downgradient well (USGS-065) from the CWP was $1.596 \mathrm{mg} / \mathrm{L}$ in the May 2015 sample and $1.633 \mathrm{mg} / \mathrm{L}$ in the October 2015 sample. The upgradient well (USGS-098) had TN concentrations in the May and October 2015 samples of $1.155 \mathrm{mg} / \mathrm{L}$ and less than $1.06 \mathrm{mg} / \mathrm{L}$, respectively. The impact of $\mathrm{TN}$ on the groundwater from the CWP appears to be minimal.

Sulfate and TDS concentrations (Tables 1 and 2) in the effluent have the potential to impact groundwater. Sulfate has high solubility and tends to move at a similar velocity as the groundwater (DEQ 2007). Only 2015 sulfate and TDS concentrations are available for USGS-098 and USGS-058. Sampling wells USGS-098 and USGS-058 was not required by the previous permit.

Sulfate concentrations in the 2015 permit year effluent monthly samples ranged from a low of $19.8 \mathrm{mg} / \mathrm{L}$ in the September 2015 sample to a high of $661 \mathrm{mg} / \mathrm{L}$ in the August 2015 sample. The TDS effluent concentrations ranged from a low of $217 \mathrm{mg} / \mathrm{L}$ in the October 2015 sample to a high of $1,330 \mathrm{mg} / \mathrm{L}$ in the August 2015 sample. There are no Reuse Permit effluent limits for sulfate and TDS. However, as discussed below, there are groundwater quality standards for these two parameters.

Figures 6 and 7 show the sulfate and TDS concentrations in samples collected from the Reuse Permit CWP monitoring wells. Sulfate and TDS data were not available for Well TRA-08 for October 2009 due to insufficient water available to collect a representative sample. Where a duplicate sample was collected, the average of the original sample and the duplicate sample were used in generating the graphs.

Well USGS-065 has the highest sulfate concentrations of the six monitoring wells. Of the six wells, USGS-065 is the closest downgradient well to the CWP. As shown in Figure 6, the sulfate concentration in well USGS-065 has remained stable at approximately $160 \mathrm{mg} / \mathrm{L}$ and below the SCS of $250 \mathrm{mg} / \mathrm{L}$.

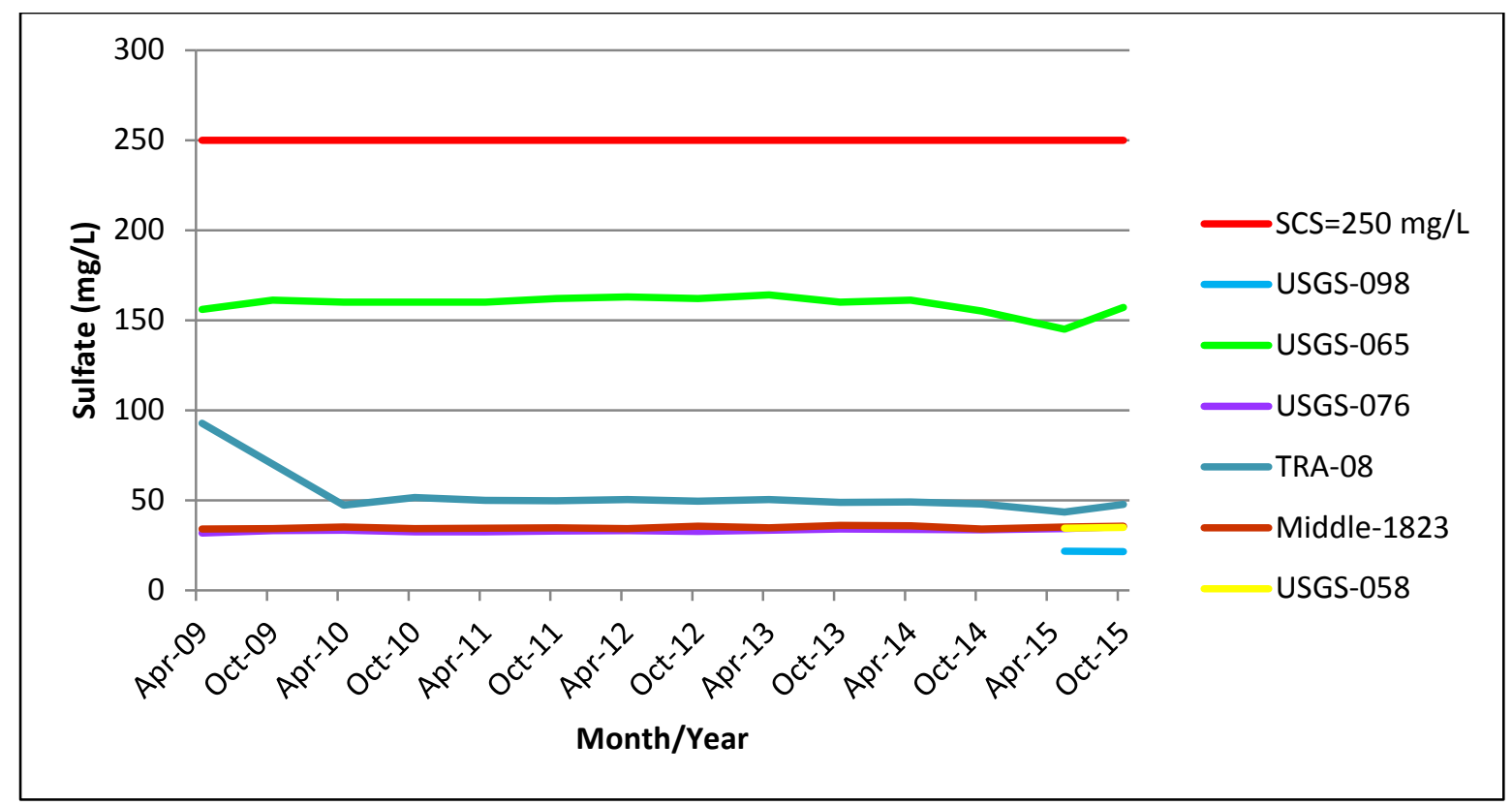

Figure 6. Sulfate concentrations in the Cold Waste Ponds monitoring wells.

Similar to sulfate, TDS concentrations was the highest in well USGS-065 (Figure 7). The highest TDS concentration in USGS-065 occurred in April 2012 at $471 \mathrm{mg} / \mathrm{L}$. The TDS concentration in USGS065 has remained below the SCS of $500 \mathrm{mg} / \mathrm{L}$ and has been relatively stable over the last 6 years. 


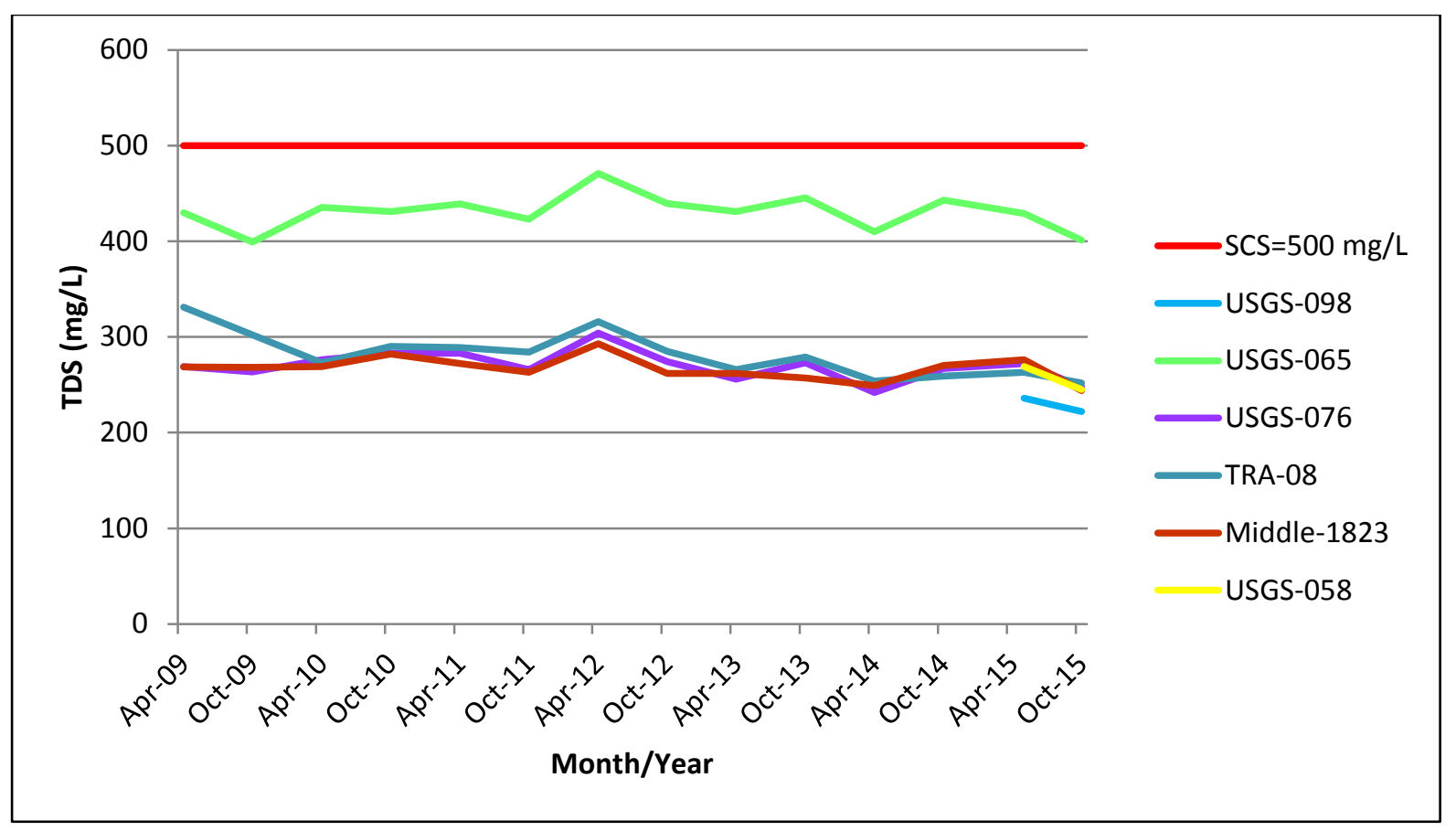

Figure 7. Total dissolved solids concentrations in the Cold Waste Ponds monitoring wells.

With the exception of USGS-065, sulfate and TDS concentrations in the groundwater wells (Figures 6 and 7) are only slightly elevated when compared to the concentrations in background well USGS-098. The sulfate and TDS quickly dissipate with distance from the ponds. This can be seen when comparing the 2015 permit year sulfate and TDS concentrations found in Wells USGS-065 and Middle-1823 (Figures 6 and 7). Well USGS-065, located approximately 1,200 ft downgradient of the CWP, had a maximum sulfate concentration of $157 \mathrm{mg} / \mathrm{L}$ and a TDS concentration of $429 \mathrm{mg} / \mathrm{L}$. Well Middle-1823, located approximately 4,000 ft downgradient from the CWP, had maximum sulfate and TDS concentrations of $35.6 \mathrm{mg} / \mathrm{L}$ and $276 \mathrm{mg} / \mathrm{L}$, respectively. The concentrations of sulfate and TDS in Well Middle-1823 are similar to the concentrations in the up/cross gradient Well USGS-076 (Figures 6 and 7).

As stated above, sulfate and TDS have SCSs for groundwater quality. The SCSs are generally based on aesthetic qualities including odor, taste, color, and foaming (EPA 1992). Sulfate is listed for causing a "salty taste" in drinking water. Total dissolved solids are listed for "hardness, deposits, colored water, staining, and salty taste." The nearest drinking water well is located approximately 3 miles downgradient of the CWP. Because the higher levels of sulfate and TDS are localized near the CWP and their SCSs are based on aesthetics, impacts to human health and the environment are expected to be minimal.

With the exception of total chromium in the May 2015 sample collected from upgradient monitoring well USGS-098, permit required groundwater sample results for aluminum, chromium, iron, and manganese, in wells USGS-065, USGS-076, TRA-08, and Middle-1823, were significantly lower than the applicable PCS or SCS (Table 4).

The May 2015 total chromium sample result from well USGS-098 was $0.149 \mathrm{mg} / \mathrm{L}$ and above the PCS $0.1 \mathrm{mg} / \mathrm{L}$. The May 2015 filtered chromium sample result from USGS-098 was reported as below the laboratory instrument's minimum detection level at $0.0025 \mathrm{mg} / \mathrm{L}$. Both the total and filtered chromium results of $0.0064 \mathrm{mg} / \mathrm{L}$ and $0.00544 \mathrm{mg} / \mathrm{L}$, respectively, from samples collected in October 2015 from USGS-098 were significantly lower than the PCS. Because well USGS-098 is an upgradient well, there should be no impact on chromium concentrations in the groundwater from the CWP. In addition, the chromium concentrations in the CWP effluent are significantly lower than the chromium 
PCS. The high total chromium sample result from well USGS-098 may have been an anomaly. Future chromium sample results from this well will be evaluated.

There are positive impacts to the environment associated with the operation of the CWP. These include returning a significant portion of the industrial wastewater to the aquifer and providing needed water for several native animal species in an otherwise semi-arid environment. 


\section{REFERENCES}

40 CFR 136, 2014, "Guidelines Establishing Test Procedures for the Analysis of Pollutants," Code of Federal Regulations, Office of the Federal Register, July 2015.

40 CFR 141, 2014, "National Primary Drinking Water Regulations," Code of Federal Regulations, Office of the Federal Register, July 2015.

40 CFR 143, 2014, "National Secondary Drinking Water Regulations," Code of Federal Regulations, Office of the Federal Register, July 2015.

DEQ, 2007, Guidance for Reclamation and Reuse of Municipal and Industrial Wastewater, Idaho Department of Environmental Quality, September 2007.

EPA, 1992, Secondary Drinking Water Regulations: Guidance for Nuisance Chemicals, EPA 810/K-92-001.

GDE-8511, “Inorganic Analyses Data Validation for INL,” Revision 0, January 25, 2007.

IDAPA 58.01.11, 2015, “Ground Water Quality Rule,” Idaho Department of Environmental Quality, June 2015.

IDAPA 58.01.17, 2011, "Recycled Water Rules,” Idaho Department of Environmental Quality, April 2011.

LI-330, 2015, "Groundwater Monitoring for the Advanced Test Reactor Complex Cold Waste Pond Industrial Wastewater Reuse Permit," Revision 4, February 27, 2015.

Mascareñas, C. S., INL, to T. Rackow, P. E., DEQ, July 23, 2013, "Comments on the Idaho National Laboratory Advanced Test Reactor Complex Cold Waste Pond, Draft Wastewater Reuse Permit (I161-02)," CCN 231018.

Miller, T. A., INL, to T. Rackow, P. E., DEQ, September 15, 2014, "Response to Draft Permit \#2 (I-16102) for Idaho National Laboratory Site's Advanced Test Reactor Complex Cold Waste Pond and Transmittal of the Completed Permit Application Form, Responsible Official/Authorized Representative Form, and Facility Information Form," CCN 233826.

Miller, T. A., INL, to G. Eager, DEQ, May 18, 2015a, "Reuse Permit I-161-02 Compliance Activity CA161-02 Quality Assurance Project Plan Transmittal," CCN 235805.

Miller, T. A., INL, to G. Eager, DEQ, November 19, 2015b, "Reuse Permit I-160-02 Compliance Activity CA-161-01 Plan of Operation Transmittal," CCN 237051.

Neher, E., DEQ, to J. A. Stenzel, INL, and V. Dugger, DOE-ID, June 25, 2013, "I-161-02 INL ATR Cold Waste Ponds, Draft Wastewater Reuse Permit," CCN 230860.

Neher, E., DEQ, to R. Boston, DOE-ID, November 20, 2014a, "I-161-02 INL ATR Cold Waste Ponds, Final Permit," CCN 234522.

Neher, E., DEQ, to S. D. Dossett, INL, and L. L. Lacroix, DOE-ID, March 26, 2014b, "I-161-02 INL ATR Cold Waste Ponds, Response to Comments and Draft Permit \#2 for Review," CCN 232837.

Rackow, T., P.E., DEQ, to J. A. Stenzel, INL, October 12, 2012a, "I-161-02 INL ATR Cold Waste Ponds, Reuse Permit Application, Completeness Determination," CCN 228797.

Rackow, T., P.E., DEQ, to J. A. Stenzel, INL, October 12, 2012b, "I-161-02 INL ATR Cold Waste Ponds, Preliminary Decision to Issue a Draft Permit," CCN 228798. 
Stenzel, J. A., INL, to E. Neher, DEQ, August 21, 2012, "Submittal of the Industrial Wastewater Reuse Permit Renewal Application for the Advanced Test Reactor Complex Cold Waste Pond," CCN 228164. 


\section{Appendix A}

\section{Daily Discharge Volumes to the Advanced Test Reactor Complex Cold Waste Ponds}




\section{Appendix A}

\section{Daily Discharge Volumes to the Advanced Test Reactor Complex Cold Waste Ponds}

Table A-1. Daily discharge volumes to the ATR Complex CWP for the 2015 permit year.

\begin{tabular}{|c|c|c|c|c|c|}
\hline Date & $\begin{array}{l}\text { North Pond } \\
\text { (gal) }\end{array}$ & $\begin{array}{l}\text { South Pond } \\
\text { (gal) }\end{array}$ & Date & $\begin{array}{l}\text { North Pond } \\
\text { (gal) }\end{array}$ & $\begin{array}{l}\text { South Pond } \\
\text { (gal) }\end{array}$ \\
\hline $11 / 01 / 14$ & OOS & 802,550 & $12 / 10 / 14$ & OOS & 732,400 \\
\hline $11 / 02 / 14$ & OOS & 772,210 & $12 / 11 / 14$ & OOS & 824,800 \\
\hline $11 / 03 / 14$ & OOS & 825,230 & $12 / 12 / 14$ & OOS & 784,200 \\
\hline $11 / 04 / 14$ & OOS & 754,360 & $12 / 13 / 14$ & OOS & 754,470 \\
\hline $11 / 05 / 14$ & OOS & 806,670 & $12 / 14 / 14$ & OOS & 776,180 \\
\hline $11 / 06 / 14$ & OOS & 698,170 & $12 / 15 / 14$ & OOS & 857,730 \\
\hline $11 / 07 / 14$ & OOS & 876,790 & $12 / 16 / 14$ & OOS & 741,430 \\
\hline $11 / 08 / 14$ & OOS & 769,760 & $12 / 17 / 14$ & OOS & 826,700 \\
\hline $11 / 09 / 14$ & OOS & 840,860 & $12 / 18 / 14$ & OOS & 804,060 \\
\hline $11 / 10 / 14$ & OOS & 701,750 & $12 / 19 / 14$ & OOS & 755,640 \\
\hline $11 / 11 / 14$ & OOS & 840,280 & $12 / 20 / 14$ & OOS & 792,600 \\
\hline $11 / 12 / 14$ & OOS & 724,790 & $12 / 21 / 14$ & OOS & 837,540 \\
\hline $11 / 13 / 14$ & OOS & 827,700 & $12 / 22 / 14$ & OOS & 788,100 \\
\hline $11 / 14 / 14$ & OOS & 955,400 & $12 / 23 / 14$ & OOS & 827,140 \\
\hline $11 / 15 / 14$ & OOS & 817,050 & $12 / 24 / 14$ & OOS & 816,250 \\
\hline $11 / 16 / 14$ & OOS & 728,500 & $12 / 25 / 14$ & OOS & 770,200 \\
\hline $11 / 17 / 14$ & OOS & 916,140 & $12 / 26 / 14$ & OOS & 866,500 \\
\hline $11 / 18 / 14$ & OOS & 669,490 & $12 / 27 / 14$ & OOS & 749,000 \\
\hline $11 / 19 / 14$ & OOS & 818,480 & $12 / 28 / 14$ & OOS & 774,000 \\
\hline $11 / 20 / 14$ & OOS & 777,780 & $12 / 29 / 14$ & OOS & 860,920 \\
\hline $11 / 21 / 14$ & OOS & 841,100 & $12 / 30 / 14$ & OOS & 719,600 \\
\hline $11 / 22 / 14$ & OOS & 777,900 & $12 / 31 / 14$ & OOS & 911,370 \\
\hline $11 / 23 / 14$ & OOS & 746,500 & $01 / 01 / 15$ & OOS & 796,620 \\
\hline $11 / 24 / 14$ & OOS & 796,610 & $01 / 02 / 15$ & OOS & 731,380 \\
\hline $11 / 25 / 14$ & OOS & 814,210 & $01 / 03 / 15$ & OOS & 873,670 \\
\hline $11 / 26 / 14$ & OOS & 799,810 & $01 / 04 / 15$ & OOS & 898,350 \\
\hline $11 / 27 / 14$ & OOS & 744,260 & $01 / 05 / 15$ & OOS & 591,600 \\
\hline $11 / 28 / 14$ & OOS & 887,460 & $01 / 06 / 15$ & OOS & 816,900 \\
\hline $11 / 29 / 14$ & OOS & 788,720 & $01 / 07 / 15$ & OOS & 888,340 \\
\hline $11 / 30 / 14$ & OOS & 808,780 & $01 / 08 / 15$ & OOS & 777,060 \\
\hline $12 / 01 / 14$ & OOS & 740,010 & $01 / 09 / 15$ & OOS & 799,300 \\
\hline $12 / 02 / 14$ & OOS & 800,700 & $01 / 10 / 15$ & OOS & 844,540 \\
\hline $12 / 03 / 14$ & OOS & 826,530 & $01 / 11 / 15$ & OOS & 789,860 \\
\hline $12 / 04 / 14$ & OOS & 797,450 & $01 / 12 / 15$ & OOS & 790,200 \\
\hline $12 / 05 / 14$ & OOS & 814,870 & $01 / 13 / 15$ & OOS & 836,810 \\
\hline $12 / 06 / 14$ & OOS & 882,430 & $01 / 14 / 15$ & OOS & 814,890 \\
\hline $12 / 07 / 14$ & OOS & 804,190 & $01 / 15 / 15$ & OOS & 818,000 \\
\hline $12 / 08 / 14$ & OOS & 794,620 & $01 / 16 / 15$ & OOS & 833,900 \\
\hline $12 / 09 / 14$ & OOS & 823,260 & $01 / 17 / 15$ & OOS & 698,000 \\
\hline
\end{tabular}




\begin{tabular}{|c|c|c|}
\hline Date & $\begin{array}{l}\text { North Pond } \\
\text { (gal) }\end{array}$ & $\begin{array}{l}\text { South Pond } \\
\text { (gal) }\end{array}$ \\
\hline $01 / 18 / 15$ & OOS & 816,280 \\
\hline $01 / 19 / 15$ & OOS & 784,020 \\
\hline $01 / 20 / 15$ & OOS & 811,190 \\
\hline $01 / 21 / 15$ & OOS & 859,430 \\
\hline $01 / 22 / 15$ & OOS & 768,780 \\
\hline $01 / 23 / 15$ & OOS & 869,300 \\
\hline $01 / 24 / 15$ & OOS & 831,300 \\
\hline $01 / 25 / 15$ & OOS & 725,700 \\
\hline $01 / 26 / 15$ & OOS & 841,300 \\
\hline $01 / 27 / 15$ & OOS & 849,000 \\
\hline $01 / 28 / 15$ & OOS & 860,000 \\
\hline $01 / 29 / 15$ & OOS & 871,810 \\
\hline $01 / 30 / 15$ & OOS & 848,790 \\
\hline $01 / 31 / 15$ & OOS & 825,550 \\
\hline $02 / 01 / 15$ & OOS & 916,240 \\
\hline $02 / 02 / 15$ & 715,910 & OOS \\
\hline $02 / 03 / 15$ & 868,200 & OOS \\
\hline $02 / 04 / 15$ & 795,900 & OOS \\
\hline $02 / 05 / 15$ & 876,700 & OOS \\
\hline $02 / 06 / 15$ & 848,810 & OOS \\
\hline $02 / 07 / 15$ & 699,810 & OOS \\
\hline $02 / 08 / 15$ & 868,510 & OOS \\
\hline $02 / 09 / 15$ & 547,020 & OOS \\
\hline $02 / 10 / 15$ & 343,450 & OOS \\
\hline $02 / 11 / 15$ & 382,960 & OOS \\
\hline $02 / 12 / 15$ & 347,640 & OOS \\
\hline $02 / 13 / 15$ & 371,370 & OOS \\
\hline $02 / 14 / 15$ & 420,530 & OOS \\
\hline $02 / 15 / 15$ & 923,190 & OOS \\
\hline $02 / 16 / 15$ & 904,570 & OOS \\
\hline $02 / 17 / 15$ & 911,280 & OOS \\
\hline $02 / 18 / 15$ & 892,300 & OOS \\
\hline $02 / 19 / 15$ & 913,210 & OOS \\
\hline $02 / 20 / 15$ & 943,000 & OOS \\
\hline $02 / 21 / 15$ & 808,900 & OOS \\
\hline $02 / 22 / 15$ & 836,050 & OOS \\
\hline $02 / 23 / 15$ & 890,000 & OOS \\
\hline $02 / 24 / 15$ & 901,230 & OOS \\
\hline $02 / 25 / 15$ & 879,820 & OOS \\
\hline $02 / 26 / 15$ & 932,290 & OOS \\
\hline $02 / 27 / 15$ & 956,380 & OOS \\
\hline $02 / 28 / 15$ & 769,260 & OOS \\
\hline $03 / 01 / 15$ & $1,016,620$ & OOS \\
\hline $03 / 02 / 15$ & 722,250 & OOS \\
\hline $03 / 03 / 15$ & 868,770 & OOS \\
\hline $03 / 04 / 15$ & 743,280 & OOS \\
\hline
\end{tabular}

\begin{tabular}{|c|c|c|}
\hline Date & $\begin{array}{l}\text { North Pond } \\
\text { (gal) }\end{array}$ & $\begin{array}{l}\text { South Pond } \\
\text { (gal) }\end{array}$ \\
\hline $03 / 05 / 15$ & 921,350 & OOS \\
\hline $03 / 06 / 15$ & 957,720 & OOS \\
\hline $03 / 07 / 15$ & 937,760 & OOS \\
\hline $03 / 08 / 15$ & $1,135,890$ & OOS \\
\hline $03 / 09 / 15$ & 850,470 & OOS \\
\hline $03 / 10 / 15$ & OOS & 659,560 \\
\hline $03 / 11 / 15$ & OOS & 430,050 \\
\hline $03 / 12 / 15$ & OOS & 417,780 \\
\hline $03 / 13 / 15$ & OOS & 479,220 \\
\hline $03 / 14 / 15$ & OOS & 433,900 \\
\hline $03 / 15 / 15$ & OOS & 388,800 \\
\hline $03 / 16 / 15$ & OOS & 426,200 \\
\hline $03 / 17 / 15$ & OOS & 462,670 \\
\hline $03 / 18 / 15$ & OOS & 460,490 \\
\hline $03 / 19 / 15$ & OOS & 431,870 \\
\hline $03 / 20 / 15$ & OOS & 440,870 \\
\hline $03 / 21 / 15$ & OOS & 435,000 \\
\hline $03 / 22 / 15$ & OOS & 449,560 \\
\hline $03 / 23 / 15$ & OOS & 412,680 \\
\hline $03 / 24 / 15$ & OOS & 434,110 \\
\hline $03 / 25 / 15$ & OOS & 452,330 \\
\hline $03 / 26 / 15$ & OOS & 412,300 \\
\hline $03 / 27 / 15$ & OOS & 568,020 \\
\hline $03 / 28 / 15$ & OOS & 327,210 \\
\hline $03 / 29 / 15$ & OOS & 509,560 \\
\hline $03 / 30 / 15$ & OOS & 372,350 \\
\hline $03 / 31 / 15$ & OOS & 398,580 \\
\hline $04 / 01 / 15$ & OOS & 456,700 \\
\hline $04 / 02 / 15$ & OOS & 462,100 \\
\hline $04 / 03 / 15$ & 424,550 & OOS \\
\hline $04 / 04 / 15$ & 449,690 & OOS \\
\hline $04 / 05 / 15$ & 427,450 & OOS \\
\hline $04 / 06 / 15$ & 477,330 & OOS \\
\hline $04 / 07 / 15$ & 430,980 & OOS \\
\hline $04 / 08 / 15$ & 515,670 & OOS \\
\hline $04 / 09 / 15$ & 425,200 & OOS \\
\hline $04 / 10 / 15$ & 483,000 & OOS \\
\hline $04 / 11 / 15$ & 456,400 & OOS \\
\hline $04 / 12 / 15$ & 422,700 & OOS \\
\hline $04 / 13 / 15$ & 459,540 & OOS \\
\hline $04 / 14 / 15$ & 429,470 & OOS \\
\hline $04 / 15 / 15$ & 433,820 & OOS \\
\hline $04 / 16 / 15$ & 446,810 & OOS \\
\hline $04 / 17 / 15$ & 482,600 & OOS \\
\hline $04 / 18 / 15$ & 351,100 & OOS \\
\hline $04 / 19 / 15$ & 430,950 & OOS \\
\hline
\end{tabular}




\begin{tabular}{|c|c|c|}
\hline Date & $\begin{array}{c}\text { North Pond } \\
\text { (gal) }\end{array}$ & $\begin{array}{c}\text { South Pond } \\
\text { (gal) }\end{array}$ \\
\hline $04 / 20 / 15$ & 436,740 & OOS \\
\hline $04 / 21 / 15$ & 445,540 & OOS \\
\hline $04 / 22 / 15$ & 439,600 & OOS \\
\hline $04 / 23 / 15$ & 517,280 & OOS \\
\hline $04 / 24 / 15$ & 403,250 & OOS \\
\hline $04 / 25 / 15$ & 481,240 & OOS \\
\hline $04 / 26 / 15$ & 538,300 & OOS \\
\hline $04 / 27 / 15$ & 346,270 & OOS \\
\hline $04 / 28 / 15$ & 544,600 & OOS \\
\hline $04 / 29 / 15$ & 412,420 & OOS \\
\hline $04 / 30 / 15$ & 549,500 & OOS \\
\hline $05 / 01 / 15$ & OOS & 546,190 \\
\hline $05 / 02 / 15$ & OOS & 547,390 \\
\hline $05 / 03 / 15$ & OOS & 586,810 \\
\hline $05 / 04 / 15$ & OOS & 569,430 \\
\hline $05 / 05 / 15$ & OOS & 558,980 \\
\hline $05 / 06 / 15$ & OOS & 616,000 \\
\hline $05 / 07 / 15$ & OOS & 625,400 \\
\hline $05 / 08 / 15$ & OOS & 610,200 \\
\hline $05 / 09 / 15$ & OOS & 573,000 \\
\hline $05 / 10 / 15$ & OOS & 679,800 \\
\hline $05 / 11 / 15$ & OOS & 840,160 \\
\hline $05 / 12 / 15$ & OOS & 711,830 \\
\hline $05 / 13 / 15$ & OOS & 752,760 \\
\hline $05 / 14 / 15$ & OOS & 821,000 \\
\hline $05 / 15 / 15$ & OOS & 638,550 \\
\hline $05 / 16 / 15$ & OOS & 786,850 \\
\hline $05 / 17 / 15$ & OOS & 735,510 \\
\hline $05 / 18 / 15$ & OOS & 755,540 \\
\hline $05 / 19 / 15$ & OOS & 764,150 \\
\hline $05 / 20 / 15$ & OOS & 787,000 \\
\hline $05 / 21 / 15$ & OOS & 811,550 \\
\hline $05 / 22 / 15$ & OOS & 798,240 \\
\hline $05 / 23 / 15$ & OOS & 758,360 \\
\hline $05 / 24 / 15$ & OOS & 752,290 \\
\hline $05 / 25 / 15$ & OOS & 706,760 \\
\hline $05 / 26 / 15$ & OOS & 736,850 \\
\hline $05 / 27 / 15$ & OOS & 918,230 \\
\hline $05 / 28 / 15$ & OOS & 698,600 \\
\hline $05 / 29 / 15$ & OOS & 619,880 \\
\hline $05 / 30 / 15$ & OOS & 315,490 \\
\hline $05 / 31 / 15$ & OOS & 289,540 \\
\hline $06 / 01 / 15$ & OOS & 303,700 \\
\hline $06 / 02 / 15$ & OOS & 47,170 \\
\hline $06 / 03 / 15$ & OOS & \\
\hline $06 / 04 / 15$ & OOS & \\
\hline & & \\
\hline & & \\
\hline 040
\end{tabular}

\begin{tabular}{|c|c|c|}
\hline Date & $\begin{array}{l}\text { North Pond } \\
\text { (gal) }\end{array}$ & $\begin{array}{l}\text { South Pond } \\
\text { (gal) }\end{array}$ \\
\hline $06 / 05 / 15$ & OOS & 338,480 \\
\hline $06 / 06 / 15$ & OOS & 438,200 \\
\hline $06 / 07 / 15$ & OOS & 419,600 \\
\hline $06 / 08 / 15$ & OOS & 435,400 \\
\hline $06 / 09 / 15$ & OOS & 426,300 \\
\hline $06 / 10 / 15$ & OOS & 518,910 \\
\hline $06 / 11 / 15$ & OOS & 380,700 \\
\hline $06 / 12 / 15$ & OOS & 443,400 \\
\hline $06 / 13 / 15$ & OOS & 441,400 \\
\hline $06 / 14 / 15$ & OOS & 408,910 \\
\hline $06 / 15 / 15$ & OOS & 427,000 \\
\hline $06 / 16 / 15$ & OOS & 415,480 \\
\hline $06 / 17 / 15$ & OOS & 526,700 \\
\hline $06 / 18 / 15$ & OOS & 352,160 \\
\hline $06 / 19 / 15$ & OOS & 421,920 \\
\hline $06 / 20 / 15$ & OOS & 456,020 \\
\hline $06 / 21 / 15$ & OOS & 402,700 \\
\hline $06 / 22 / 15$ & OOS & 433,250 \\
\hline $06 / 23 / 15$ & OOS & 432,460 \\
\hline $06 / 24 / 15$ & OOS & 384,790 \\
\hline $06 / 25 / 15$ & OOS & 456,500 \\
\hline $06 / 26 / 15$ & OOS & 494,210 \\
\hline $06 / 27 / 15$ & OOS & 377,100 \\
\hline $06 / 28 / 15$ & OOS & 455,190 \\
\hline $06 / 29 / 15$ & OOS & 467,950 \\
\hline $06 / 30 / 15$ & OOS & 435,510 \\
\hline $07 / 01 / 15$ & 410,840 & OOS \\
\hline $07 / 02 / 15$ & 490,800 & OOS \\
\hline $07 / 03 / 15$ & 407,360 & OOS \\
\hline $07 / 04 / 15$ & 403,200 & OOS \\
\hline $07 / 05 / 15$ & 447,660 & OOS \\
\hline $07 / 06 / 15$ & 431,780 & OOS \\
\hline $07 / 07 / 15$ & 476,970 & OOS \\
\hline $07 / 08 / 15$ & 408,760 & OOS \\
\hline $07 / 09 / 15$ & 454,360 & OOS \\
\hline $07 / 10 / 15$ & 427,010 & OOS \\
\hline $07 / 11 / 15$ & 424,300 & OOS \\
\hline $07 / 12 / 15$ & 434,900 & OOS \\
\hline $07 / 13 / 15$ & 481,600 & OOS \\
\hline $07 / 14 / 15$ & 401,850 & OOS \\
\hline $07 / 15 / 15$ & 423,390 & OOS \\
\hline $07 / 16 / 15$ & 514,700 & OOS \\
\hline $07 / 17 / 15$ & 477,750 & OOS \\
\hline $07 / 18 / 15$ & 427,100 & OOS \\
\hline $07 / 19 / 15$ & 431,410 & OOS \\
\hline $07 / 20 / 15$ & 457,570 & OOS \\
\hline
\end{tabular}




\begin{tabular}{|c|c|c|}
\hline Date & $\begin{array}{c}\text { North Pond } \\
\text { (gal) }\end{array}$ & $\begin{array}{c}\text { South Pond } \\
\text { (gal) }\end{array}$ \\
\hline $07 / 21 / 15$ & 485,230 & OOS \\
\hline $07 / 22 / 15$ & 420,700 & OOS \\
\hline $07 / 23 / 15$ & 689,950 & OOS \\
\hline $07 / 24 / 15$ & 687,350 & OOS \\
\hline $07 / 25 / 15$ & 756,560 & OOS \\
\hline $07 / 26 / 15$ & 739,360 & OOS \\
\hline $07 / 27 / 15$ & 602,560 & OOS \\
\hline $07 / 28 / 15$ & 603,880 & OOS \\
\hline $07 / 29 / 15$ & 636,570 & OOS \\
\hline $07 / 30 / 15$ & 674,500 & OOS \\
\hline $07 / 31 / 15$ & 731,900 & OOS \\
\hline $08 / 01 / 15$ & OOS & 622,900 \\
\hline $08 / 02 / 15$ & OOS & 723,570 \\
\hline $08 / 03 / 15$ & OOS & 574,540 \\
\hline $08 / 04 / 15$ & OOS & 474,160 \\
\hline $08 / 05 / 15$ & OOS & 574,060 \\
\hline $08 / 06 / 15$ & OOS & 445,030 \\
\hline $08 / 07 / 15$ & OOS & 182,700 \\
\hline $08 / 08 / 15$ & OOS & 181,700 \\
\hline $08 / 09 / 15$ & OOS & 234,260 \\
\hline $08 / 10 / 15$ & OOS & 272,700 \\
\hline $08 / 11 / 15$ & OOS & 355,230 \\
\hline $08 / 12 / 15$ & OOS & 696,920 \\
\hline $08 / 13 / 15$ & OOS & 568,560 \\
\hline $08 / 14 / 15$ & OOS & 407,140 \\
\hline $08 / 15 / 15$ & OOS & 567,250 \\
\hline $08 / 16 / 15$ & OOS & 526,420 \\
\hline $08 / 17 / 15$ & OOS & 514,940 \\
\hline $08 / 18 / 15$ & OOS & 574,090 \\
\hline $08 / 19 / 15$ & OOS & 595,650 \\
\hline $08 / 20 / 15$ & OOS & 523,350 \\
\hline $08 / 21 / 15$ & OOS & 610,250 \\
\hline $08 / 22 / 15$ & OOS & 661,350 \\
\hline $08 / 23 / 15$ & OOS & 591,300 \\
\hline $08 / 24 / 15$ & OOS & 667,450 \\
\hline $08 / 25 / 15$ & OOS & 543,370 \\
\hline $08 / 26 / 15$ & OOS & 608,980 \\
\hline $08 / 27 / 15$ & OOS & 731,200 \\
\hline $08 / 28 / 15$ & OOS & 651,800 \\
\hline $08 / 29 / 15$ & OOS & 642,500 \\
\hline $08 / 30 / 15$ & OOS & 493,480 \\
\hline $08 / 31 / 15$ & OOS & 630,820 \\
\hline $09 / 01 / 15$ & 551,900 & 670,030 \\
\hline $09 / 02 / 15$ & 645,100 & OOS \\
\hline $09 / 03 / 15$ & & \\
\hline $09 / 04 / 15$ & 616,40 & OOS \\
\hline & & \\
\hline & & \\
\hline 000
\end{tabular}

\begin{tabular}{|c|c|c|}
\hline Date & $\begin{array}{c}\text { North Pond } \\
\text { (gal) }\end{array}$ & $\begin{array}{c}\text { South Pond } \\
\text { (gal) }\end{array}$ \\
\hline $09 / 05 / 15$ & 599,500 & OOS \\
\hline $09 / 06 / 15$ & 635,000 & OOS \\
\hline $09 / 07 / 15$ & 572,220 & OOS \\
\hline $09 / 08 / 15$ & 634,980 & OOS \\
\hline $09 / 09 / 15$ & 644,290 & OOS \\
\hline $09 / 10 / 15$ & 565,550 & OOS \\
\hline $09 / 11 / 15$ & 899,730 & OOS \\
\hline $09 / 12 / 15$ & 650,000 & OOS \\
\hline $09 / 13 / 15$ & 600,610 & OOS \\
\hline $09 / 14 / 15$ & 593,620 & OOS \\
\hline $09 / 15 / 15$ & 590,170 & OOS \\
\hline $09 / 16 / 15$ & 559,830 & OOS \\
\hline $09 / 17 / 15$ & 645,000 & OOS \\
\hline $09 / 18 / 15$ & 617,800 & OOS \\
\hline $09 / 19 / 15$ & 488,250 & OOS \\
\hline $09 / 20 / 15$ & 506,790 & OOS \\
\hline $09 / 21 / 15$ & 551,600 & OOS \\
\hline $09 / 22 / 15$ & 490,490 & OOS \\
\hline $09 / 23 / 15$ & 590,760 & OOS \\
\hline $09 / 24 / 15$ & 542,310 & OOS \\
\hline $09 / 25 / 15$ & 398,250 & OOS \\
\hline $09 / 26 / 15$ & 457,750 & OOS \\
\hline $09 / 27 / 15$ & 555,480 & OOS \\
\hline $09 / 28 / 15$ & 464,050 & OOS \\
\hline $09 / 29 / 15$ & 573,390 & OOS \\
\hline $09 / 30 / 15$ & 525,780 & OOS \\
\hline $10 / 01 / 15$ & OOS & 500,400 \\
\hline $10 / 02 / 15$ & OOS & 602,300 \\
\hline $10 / 03 / 15$ & OOS & 537,300 \\
\hline $10 / 04 / 15$ & OOS & 532,100 \\
\hline $10 / 05 / 15$ & OOS & 530,900 \\
\hline $10 / 06 / 15$ & OOS & 545,700 \\
\hline $10 / 07 / 15$ & OOS & 562,070 \\
\hline $10 / 08 / 15$ & OOS & 595,930 \\
\hline $10 / 09 / 15$ & OOS & 540,040 \\
\hline $10 / 10 / 15$ & OOS & 615,430 \\
\hline $10 / 11 / 15$ & OOS & 520,830 \\
\hline $10 / 12 / 15$ & OOS & 623,530 \\
\hline $10 / 13 / 15$ & OOS & 612,260 \\
\hline $10 / 14 / 15$ & OOS & 574,510 \\
\hline $10 / 15 / 15$ & OOS & 564,300 \\
\hline $10 / 16 / 15$ & OOS & 694,500 \\
\hline $10 / 17 / 15$ & OOS & 510,000 \\
\hline $10 / 18 / 15$ & OOS & 618,560 \\
\hline $10 / 19 / 15$ & OOS & 640,480 \\
\hline $10 / 20 / 15$ & 545,460 \\
\hline
\end{tabular}




\begin{tabular}{|c|c|c|}
\hline Date & $\begin{array}{c}\text { North Pond } \\
\text { (gal) }\end{array}$ & $\begin{array}{c}\text { South Pond } \\
\text { (gal) }\end{array}$ \\
\hline $10 / 21 / 15$ & OOS & 614,190 \\
\hline $10 / 22 / 15$ & OOS & 634,500 \\
\hline $10 / 23 / 15$ & OOS & 515,800 \\
\hline $10 / 24 / 15$ & OOS & 547,900 \\
\hline $10 / 25 / 15$ & OOS & 521,300 \\
\hline $10 / 26 / 15$ & OOS & 558,280 \\
\hline
\end{tabular}

\begin{tabular}{|c|c|c|}
\hline Date & $\begin{array}{c}\text { North Pond } \\
\text { (gal) }\end{array}$ & $\begin{array}{c}\text { South Pond } \\
\text { (gal) }\end{array}$ \\
\hline $10 / 27 / 15$ & OOS & 575,940 \\
\hline $10 / 28 / 15$ & OOS & 549,010 \\
\hline $10 / 29 / 15$ & OOS & 494,190 \\
\hline $10 / 30 / 15$ & OOS & 562,130 \\
\hline $10 / 31 / 15$ & OOS & 592,020 \\
\hline \multicolumn{3}{|c|}{ a. OOS indicates pond was out of service. } \\
\hline
\end{tabular}

